\title{
Does Portfolio Disclosure Make Money Smarter?*
}

\author{
Byoung Uk Kang ${ }^{\dagger} \quad$ Andrew J. Sinclair ${ }^{\ddagger} \quad$ Stig J. Xeno ${ }^{\S}$
}

November 18, 2019

\begin{abstract}
We document the benefits of mandatory portfolio disclosure in the hedge fund market. We study investor purchasing and selling decisions, captured by hedge fund flows. After a fund begins filing Form 13F with the Securities and Exchange Commission, we find that investor flows are better able to predict fund performance (i.e., money becomes "smarter"). In particular, the spread in performance between high- and low-flow funds is 3.7 percentage points higher for 13F-filing funds compared with non-filers. We analyze cross-sectional differences in the precision, usefulness, and access of information, and find evidence that the increase in smart money is driven by the information channel. In addition, using a subset of funds of hedge funds ("FoFs") for which we have holdings data, we find that FoFs earn superior returns on their portfolios of $13 \mathrm{~F}$-filing hedge funds. These results help contribute to the cost-benefit analysis of mandatory disclosure.
\end{abstract}

${ }^{*}$ We are grateful to Vikas Agarwal, Dong Lou, David McLean, Christo Pirinsky, and Mengxin Zhao for valuable feedback.

†School of Accounting and Finance, The Hong Kong Polytechnic University, Hung Hom, Kowloon, Hong Kong, e-mail: byoung.kang@polyu.edu.hk.

${ }^{\ddagger}$ Faculty of Business and Economics, The University of Hong Kong, K.K. Leung Building, Pokfulam Road, Hong Kong, e-mail: andrew.sinclair@hku.hk.

${ }^{\S}$ School of Accounting and Finance, The Hong Kong Polytechnic University, Hung Hom, Kowloon, Hong Kong, e-mail: jeremy.yh.qiu@connect.polyu.hk. 


\section{Introduction}

Since 1979, hedge funds have been required to publicly disclose their quarterly equity holdings via Form 13F filed with the Securities and Exchange Commission ("SEC"). This disclosure of proprietary information is costly; it induces copycat trading and leads to large reductions in fund returns. ${ }^{1}$ However, both the SEC and the public have long held the view that portfolio disclosure benefits fund investors. ${ }^{2}$ They claim that Form $13 \mathrm{~F}$ helps investors evaluate fund managers, and make more informed (i.e., smarter) investment decisions. Indeed, Agarwal, Ruenzi, and Weigert (2018c) demonstrate that Form 13F helps the econometrician predict hedge fund performance. ${ }^{3}$ In this paper, we provide evidence that real-world investors use the information contained in 13F filings, and this information helps improve their fund selection ability.

In particular, we study how public disclosure affects aggregate investor decisions, proxied using the quarterly net fund flows into a given hedge fund. We employ a "follow the money" approach, to see whether investments subsequently lead to good performance, and whether divestments avoid bad performance. This relationship between past fund flows and future performance (if it exists) is referred to as the "smart money" effect in the literature. ${ }^{4}$ We

\footnotetext{
${ }^{1}$ Brown and Schwarz (2013) document evidence that copycat traders mimic trades revealed in public hedge fund disclosure. Shi (2017) quantifies the cost of public disclosure, and finds that after funds disclose their holdings, their average risk-adjusted performance drops by about 2.7 percentage points annually. Cao, Du, Yang, and Zhang (2018) use the SEC EDGAR log files, combined with public disclosure reported on Form $13 \mathrm{~F}$ to identify copycats and targets. They find that copycats induce a performance loss of 2.56 p.p. on target funds.

${ }^{2}$ The SEC solicited public feedback after it announced the adoption of Rule 13f-1, which required quarterly reporting. The SEC received 124 letters, and the SEC remarked:

A number of commentators pointed out that quarterly reporting would provide a greater basis for comparison shopping among investment managers. Such commentators emphasized that an evaluation of the investment philosophy and policies of a prospective manager is crucial in making an effective comparison and that such an evaluation is dependent upon a periodic examination of a manager's investment decisions as reflected by his holdings transactions.

(See: Securities and Exchange Act of 1934 Release No. 15461. January 5, 1979.)

${ }^{3}$ Kacperczyk, Sialm, and Zheng $(2005,2008)$ and Cremers and Petajisto (2009) also demonstrates in the mutual fund market that the portfolio information contained in public disclosure predicts mutual fund returns.

${ }^{4}$ See Gruber (1996), Zheng (1999), and Sapp and Tiwari (2004) for a discussion of the smart money effect among mutual fund investors, and Baquero and Verbeek (2005), Getmansky, Liang, Schwarz, and Wermers (2015b), and Ozik and Sadka (2015) for discussion of smart money in the hedge fund market.
} 
study (1) how the smart money effect differs among hedge funds that file Form $13 \mathrm{~F}$ and those that do not, and (2) at the firm-level, how the smart money effect changes after the fund begins filing Form 13F.

Our setting is similar to Shi (2017), who was the first to quantify the negative impact of public disclosure on fund performance. We use a fund-time panel of fund flows and performance to study how the impact of $13 \mathrm{~F}$ filing requirements affects the sensitivity of future performance to past fund flows. This setting enjoys several features that are important for causally identifying the costs and benefits of regulation (Leuz and Wysocki, 2016). (1) The initial law requiring portfolio disclosure is plausibly exogenous to the hedge fund market. Congress enacted section $13(\mathrm{f})$ in $1975,{ }^{5}$ in order to give the SEC power to monitor the market impact of all institutional investors (e.g., banks, mutual funds, pension plans, etc.). ${ }^{6}$ At the time, the hedge fund market was still in its infancy. (2) There is a threshold condition for filing $13 \mathrm{~F}$. A firm is required to file Form $13 \mathrm{~F}$ once it invests more than $\$ 100$ million in 13(f) securities. ${ }^{7}$ This provides treatment and control groups. (3) Form $13 \mathrm{~F}$ is filed at the parent company level, and a parent might have several hedge funds. Thus, for two otherwise identical funds, one might belong to a filing parent, and the other might belong to a nonfiling parent. Indeed, there is a large overlap in the distribution of fund size between the control and treatment groups, ${ }^{8}$ and this allows us to control for fund size. (4) The filing threshold yields a staggered panel, thus firms (and by transitivity, funds) cross the threshold at different times. This allows us to control for market-wide effects that may impact all filers.

We study the smart money effect in two ways. First, we employ a portfolio-based analysis.

\footnotetext{
${ }^{5}$ See: Pub. L. No. 94-29, 89 Stat. 119 (1975) available at https://www.govinfo.gov/content/pkg/ STATUTE-89/pdf/STATUTE-89-Pg97.pdf\#page=25.

${ }^{6}$ See Report of Senate Comm. on Banking, Housing and Urban Affairs, S. Rep. No. 75, 94th Cong., 1st Sess. 85 (1975). The Senate noted the need for regulators to monitor the influence and impact of institutional investors on the securities markets. In particular, to ensure investor confidence in equity markets.

${ }^{7} 13$ (f) securities typically equity securities registered with the SEC under Section 12 of the Securities and Exchange Act. The SEC provides a full list of all 13(f) securities every quarter to facilitate the filing of Form 13F: https://www.sec.gov/divisions/investment/13flists.htm.

${ }^{8}$ See Figure 1 in Shi (2017) for a distribution of fund size for the treatment and control groups.
} 
We double-sort hedge funds based on $13 \mathrm{~F}$ filing status (i.e., whether they have previously filed $13 \mathrm{~F}$ or not), and then, within each group, we sort funds into quartiles by past fund flows. In each filing-status group, we form a long-short portfolio by longing the the high-flow funds (top quartile), and shorting the low-flow funds (bottom quartile). We consider this portfolio to be a dollar-neutral measure of smart money, and is similar in construction to the main smart money analysis performed in Zheng (1999) and Sapp and Tiwari (2004).

We compare the high-low flow portfolio for filers versus non-filers, and find evidence that the smart money effect is larger among filing funds, compared to non-filers. In particular, the difference in performance spread is 34 basis points ("bps") of monthly excess returns and 31 bps of monthly Fung and Hsieh (2001) seven-factor ("FH7") alpha. Annualized, this spread is approximately 3.7 percentage points ("p.p.") of FH7 alpha.

Our results provide evidence that investors make smarter allocation decisions to funds that publicly disclose their holdings. We document a potential benefit of hedge fund portfolio disclosure. In comparison, Shi (2017) finds that hedge fund performance among $13 \mathrm{~F}$ filers is about 4.6 p.p. lower than among non-filers. ${ }^{9}$ Her results show an average level-shift down in fund performance, which ultimately reduces the returns enjoyed by investors. Our results demonstrate a change in slope; investors are better able to choose the good funds, and avoid the bad funds.

However, our smart money portfolio is not investible, and thus, we cannot claim this benefit accrues to the average investor. To more precisely measure the impact of disclosure on investors' fund selection ability, we take advantage of our staggered panel data structure to estimate longitudinal changes in the smart money effect. Our variable of interest is the "smartness" of fund flows, that is, the beta coefficient on a regression of future performance on past fund flows. We are interested in how the slope of this relationship changes after a fund becomes a $13 \mathrm{~F}$ filer. This can be thought of as a standard panel diff-in-diff where the post indicator is interacted with fund flows. In particular, our specification is similar to Lel

\footnotetext{
${ }^{9}$ See Panel B of Table 2 in Shi (2017).
} 
and Miller (2015) and Jayaraman and Wu (2018), who also study the effect of a staggered treatment on a slope, but in a corporate finance setting.

In our regression setting, we verify that the smart money effect increases after a fund starts filing Form 13F. We address endogeneity concerns by verifying the result holds in a regression discontinuity ("RD") analysis and in a placebo test using fund-of-hedge funds ("FoFs"). We also estimate specifications that use alternative measures of performance, alternative sub-samples, and alternative sets of control variables. Our results remain robust in each test. In our RD analysis, after a fund starts filing, an additional 10 p.p. of fund flows predicts 1.93 p.p. higher future annualized FH7 alpha. This compares with with an average decrease in FH7 alpha of 2.7 p.p. annually, documented by Shi (2017). ${ }^{10}$

Furthermore, our cross-sectional tests provide evidence that the increase in smart money is due to the information content of portfolio disclosure. We find that the smart money effect is driven by cases where: (1) the information about a fund's portfolio holdings is more precise, i.e., when the fund belongs to a single-fund firm or when the fund is the largest one among those managed by the firm; (2) investors have more opportunity to use the information, i.e., when the fund imposes less restrictions on redemptions and/or subscriptions; and (3) information is more frequently viewed. Taken together, these results provide evidence that investors use the information disclosed in $13 \mathrm{~F}$ filings to evaluate fund managers, and that this improves their fund selections.

We additionally supplement our fund-level flow-based analysis with an investor-level holdings-based analysis. Conceptually, our within-investor analysis controls for investor-level fixed effects. Our analysis asks, for a given investor, does their portfolio of $13 \mathrm{~F}$-filing hedge funds perform better than their portfolio of non-filers? Investor-level hedge fund portfolios are available for a small subset of investors. We have portfolio holdings for 127 registered FoFs. ${ }^{11}$

\footnotetext{
${ }^{10}$ See Column 3 of Table 3 in Shi (2017).

${ }^{11}$ There are a small number of FoFs who are registered with the SEC, and are required to disclose their portfolio holding on a quarterly basis via SEC Form N-Q, N-CSR, and N-CSRS. See Aiken, Clifford, and Ellis (2013), Agarwal, Aragon, and Shi (2018a), Gao, Haight, and Yin (2019) and Sialm, Sun, and Zheng
} 
For each FoF, we form two value-weighted portfolios rebalanced quarterly, consisting of 13F-filing hedge funds and non-filing hedge funds. We find that the average FoF earns 6.49 p.p. annually on its portfolio of filers, versus 5.52 p.p. annually on its portfolio of non-filers, for a spread of 0.97 percentage points. This result provides evidence that FoFs make smarter allocations in the universe of 13F-filing hedge funds. By controlling for investor specific characteristics (e.g., sophistication), this result provides evidence against the possibility that our main results might be driven by a clientele effect (e.g., smarter investors just happen to choose among $13 \mathrm{~F}$ filers for reasons unrelated to the information channel). Our investor-level analysis helps rule out this reverse-causality story.

Our paper contributes to the cost-benefit analysis of $13 \mathrm{~F}$ portfolio disclosure. The extant literature has largely found evidence that disclosure impairs the ability of fund managers to utilize their proprietary information, ${ }^{12}$ leading to lower returns for their clients. Shi (2017) documents that hedge fund performance drops by 2.7 p.p. annually following disclosure. Brown and Schwarz (2013) and Cao et al. (2018) document evidence of copycat trading, and Cao et al. (2018) finds that the existence of one copycat decreases target fund performance by 2.56 p.p. annually. These costs represent a level-shift down in performance, whereas our benefits describe an increase in the selection ability of investors.

Our results, by demonstrating that investors make smarter decisions, provide a counterbalance to the documented costs of public disclosure, and has potential general equilibrium implications. ${ }^{13}$ For example, if a decrease in returns were the only effect, then we might expect to see that disclosure is negatively related to price efficiency in public markets, as it dilutes the incentives for asset managers to collect and process information. However, our documented increase in the smartness of money can potentially offset the decrease in price efficiency. Disclosure helps investors source better hedge fund managers, which implies that (2019) for examples of recent work that uses portfolio data from registered FoFs.

${ }^{12}$ Aragon, Hertzel, and Shi (2013) and Agarwal, Jiang, Tang, and Yang (2013) demonstrate that 13F filings may contain proprietary information. They demonstrate that hedge funds earn higher returns when they can avoid public disclosure.

${ }^{13}$ See Cochrane (2014) for a discussion of the general equilibrium challenges of drawing inferences from the cost-benefit analysis of financial regulation. 
informed managers receive more capital. As the efficiency of asset prices is linked to the efficiency of the asset management market (Gârleanu and Pedersen, 2018), the total effect of public disclosure on price efficiency is thus ambiguous.

This cost-benefit analysis is important for understanding the effect of portfolio disclosure on economic welfare and, in particular, whether this is "good for society" (Shiller, 2013; Zingales, 2015). In the hedge fund market, the client base has shifted from wealthy individuals to large institutional investors. Institutional investors now comprise about $85 \%$ of all hedge fund clients. These investors manage the pension plans, insurance claims, and endowments of a society. If regulation can help these institutional investors choose better hedge fund managers, then this is potentially a large gain to the wealth portfolio of a wide cross-section of society.

Finally, we add to the body of literature that studies the selection ability of registered FoFs. Aiken, Clifford, and Ellis (2015) find limited evidence that FoFs exhibit skill when "hiring" hedge funds, but strong evidence that FoFs make skillful "firing" decisions. Furthermore, Gao et al. (2019) find that FoFs exhibit skill when rebalancing their portfolios. Our results shed light a potential source of such skill, by documenting that FoFs earn higher returns from their investments in 13F-filing hedge funds. More recently, Sialm et al. (2019) find evidence that FoFs have an informational advantage in assessing the prospects of nearby hedge funds. Relatedly, in a subsample analysis we find evidence that FoFs benefit more from $13 \mathrm{~F}$ disclosure when assesing geographically distant hedge funds.

The remainder of the paper is structured as follows: Section 2 discusses the institutional details, data, and variable construction; Section 3 provides the portfolio-based analysis and the difference-in-difference analysis; Section 4 presents our cross-sectional analysis of information content; Section 5 presents holdings-based analysis using FoFs; and Section 6 concludes. 


\section{Institutional Detail, Data, and Variable Construc- tion}

\subsection{Institutional Details}

\subsubsection{A Brief History of Section 13(f)}

Since 1978, large institutional investment managers ${ }^{14}$ have been required to report the details of equity holdings under their discretion to the Securities and Exchange Commission ("SEC"). ${ }^{15}$ This requirement was mandated by section 13(f) of the Securities Exchange Act of 1934 ("the 1934 Act"), which was enacted primarily to create a centralized dataset of the investment activities of institutional managers. This data was intended for regulators and the public to study the influence and impact of institutional managers on the securities markets. As an unintented consequence, Form $13 \mathrm{~F}$ quickly became an important tool for investors to evaluate the performance of investment managers.

In the $1960 \mathrm{~s}$, the public became increasingly concerned about the role of institutional investors contributing the speculative atmosphere of the securities markets. ${ }^{16}$ This was in part due to the increasing presence of institutional investors in financial markets. In 1960, institutional investment managers accounted for about $20 \%$ of all trading activity on the New York Stock Exchange ("NYSE"). ${ }^{17}$ By 1966, this figure had more than doubled to $43 \%,{ }^{18}$ and by the early 1970s, Jensen (1976) estimates this may have grown to $67 \%$ of all trading on the NYSE.

In 1968, the United States Congress directed the SEC to study the effect of institutional investors on financial markets. In March 1971, the SEC published the results in its In-

\footnotetext{
${ }^{14}$ Including banks, investment companies, pension funds, insurance companies, and brokerage houses.

${ }^{15}$ Lemke and Lins (1987) provide an excellent discussion of the history and background leading up to the enactment of section $13(\mathrm{f})$.

${ }^{16}$ Institutional Investor Study Report, H.R. Doc. No. 64, 92d Cong., 1st Sess. XXXI-XXXIII (1971)

${ }^{17}$ See Staff of House Comm. on Energy and Commerce, 99th Cong., 2d Sess., Restructuring Financial Markets: The Major Policy Issues 269 (Comm. Print 1986)

${ }^{18}$ See Biel, Why Institutional Investors Control the Stock Market's Future Course, Comm. \& Fin. July 27,1967 , at 1,24 .
} 
stitutional Study. ${ }^{19}$ The Institutional Study did not find evidence that large institutional investors harmed market efficiency. However, it noted the difficulties it encountered in conducting the study, and recommended the 1934 Act be amended to give the SEC authority to require disclosure of holdings and transactions data.

On June 4, 1975, Congress enacted section 13(f) as part of the Securities Act Amendments of $1975 .^{20}$ The legislative history of the act sheds light on the intended impact of section 13(f). When considering the proposal, the Senate noted:

Perhaps the most important justification for the information collection program which this bill would authorize is the need to collect and disseminate to individual investors data about institutional investment managers. Many people believe that it is not possible to make informed investment decisions on a security without information related to the likely market activity and the degree of institutional concentration in the security. ... [W]hat is important is that information about the securities holdings and certain transactions of institutional managers be available to all investors - both institutional and individual - so that they can all have it, whatever its relative usefulness in making their independent judgments. Thus, with the dissemination of data about institutional managers, an institutional disclosure program should stimulate a higher degree of confidence among all investors in the integrity of our securities markets. ${ }^{21}$

While the stated intent of the disclosure requirement is to increase the transparency of large influential institutional investors, market participants quickly learned that the information reported on $13 \mathrm{~F}$ could be used to evaluate investment managers. By 1987, various publications regularly published evaluations and ratings of managers based on data collected from 13F filings (Lemke and Lins, 1987).

\footnotetext{
${ }^{19}$ Institutional Investor Study Report, H.R. Doc. No. 64, 92d Cong., 1st Sess. XXXI-XXXIII (1971)

${ }^{20}$ Pub. L. No. 94-29, 89 Stat. 119 (1975)

${ }^{21}$ Report of Senate Comm. on Banking, Housing and Urban Affairs, S. Rep. No. 75, 94th Cong., 1st Sess. 85 (1975)
} 
The use of section 13(f) portfolio disclosures was not originally intended to be used by the investing public to evaluate portfolio managers. Furthermore, since 2011 private fund managers (including hedge fund managers) have been required to report position-level data regularly with the SEC on Form PF. The original intent of section 13(f) was to allow the SEC to monitor the behavior of large institutional investors. Hedge funds are now required to privately report much more detailed data directly to the government through Form PF.

\subsubsection{Form 13F Filing Requirements}

Currently, institutional investment managers are required to file Form $13 \mathrm{~F}$ on a quarterly basis. The obligation to file is triggered whenever the management company has discretion over assets totaling at least $\$ 100$ million. Specifically, in a particular calendar year, if the assets of a management company are above the $\$ 100$ million threshold as of the last trading day of any month, then the firm will be required to file Form 13F starting as of December 31st. It will subsequently file as of March 31st, June 30th, and September 30th, regardless of the current value of assets under management.

The investment manager is required to report a schedule of investments, which includes: (1) the name of the issuer; (2) the title and class of the security; (3) the CUSIP number of the security; (4) the fair market value of the holding, using the value on the last trading day of the quarter; (5) the total number of shares held; (6) whether the manager has sole or shared discretion over the assets; (7) a list of the other managers that have discretion over this asset holding; and (8) whether the manager has sole, shared, or no voting authority over the shares held.

The $\$ 100$ million asset threshold described above is based on the company's holdings of section 13(f) securities. Section 13(d)(1) describes which types of equity securities are required to be considered. However, Rule 13(f)(1) effectively limits this set to only those equities that trade on a national securities exchange or are quoted on the NASDAQ.

Firms are required to report their long position of section 13(f) securities, and their 
option positions where the underlying security is a section 13(f) security. Generally, short equity positions and bond positions are not reported. Foreign equity positions are also not included.

A key difficulty in our analysis is that 13F filings are made at the management company level. Form 13F aggregates the total long positions across the entire firm. If a management company only offers one hedge fund product, then its Form $13 \mathrm{~F}$ will reflect the asset holding of that hedge fund product. However, if the management company offers multiple hedge fund products, or a mix of hedge fund and mutual fund products, then its Form 13F will be reported at the aggregate company level, and we will not be able to back out the holdings of individual funds. In our sample, about $42 \%$ of observations are from single-fund companies, where we (and investors) can directly observe the assets of the underlying fund.

\subsection{Data and Variable Construction}

\subsubsection{Sample Selection}

Our sample of hedge funds comes from the Thompson Reuters Lipper TASS database. For each listed fund, the database provides monthly net-of-fee returns and assets-undermanagement ("AUM"), a snapshot of characteristics, and the name of the parent management company. As of December 2016, TASS contains a total of 20,094 live and graveyard funds. Following prior literature, ${ }^{22}$ we require our sample of funds to: report monthly, report returns and AUM denominated in U.S. dollars, report returns net-of-fees, and list a hedge fund style. We also remove observations before 1994 in order to control for survivorship bias. To control for backfill bias, we further exclude the first eighteen months of returns for each fund. To estimate alphas, we also require at least twenty-four months of return observations. Next, we only include funds that report a management company, otherwise we cannot link these firms to Form 13F. We then drop FoFs, as these do not hold equity positions. Finally,

\footnotetext{
${ }^{22}$ In particular, we follow the cleaning guides recommended by Bhardwaj, Gorton, and Rouwenhorst (2014) and Getmansky, Lee, and Lo (2015a).
} 
we follow Aggarwal and Jorion (2010) and correct for master-feeder duplicates, resulting in a sample of 4,398 unique hedge funds managed by 2,600 management firms.

We next identify whether a hedge fund belongs to an parent company that is subject to $13 \mathrm{~F}$ reporting requirements. Quarterly $13 \mathrm{~F}$ reports are filed with the SEC and are publicly available on the EDGAR system. We obtain the full list of corporate filings from the EDGAR index files as of June 2017. ${ }^{23}$ We focus on the subset of companies that have filed at least one $13 \mathrm{~F}$ report, and match them with the list of management firms in TASS. ${ }^{24} \mathrm{~A}$ fundquarter observation is defined as "filer" if investor (i.e., the public) has access to at least one $13 \mathrm{~F}$ report at the beginning of the quarter. Because the first batch of $13 \mathrm{~F}$ filings available in EDGAR index files is filed during the second quarter of 1999, our sample starts in the third quarter of 1999. ${ }^{25}$ Following Shi (2017), we exclude observations after a fund's very last $13 \mathrm{~F}$ report; we also exclude the two fund-quarter observations around the first ever $13 \mathrm{~F}$ report (namely, the last "non-filer" quarter and the first "filer" quarter) in our main analysis. $^{26}$ Finally, to be included in the sample, an observation must have non-missing fund characteristics, including fund flow, lagged fund size, fund age, lagged fund flow, lagged fund return, and return volatility. Our main sample consists of 2,824 funds from 1,775 management firms, among which 325 funds (from 226 management firms) changed filing status from non-13F filer to $13 \mathrm{~F}$ filer in the sample period ("switchers"). ${ }^{27}$ These switching

\footnotetext{
${ }^{23}$ The index files can be found here: https://www.sec.gov/Archives/edgar/full-index/.

${ }^{24}$ Throughout the paper, we consider the following SEC form types to be $13 \mathrm{~F}$ report: 13F-E, 13F-E/A, 13F-HR, 13F-HR/A, 13F-NT, 13F-NT/A, 13FCONP, and 13FCONP/A.

${ }^{25}$ On January 12, 1999, the SEC adopted a rule requiring Form 13F reports to be filed in electronic format (effective on April 1, 1999). Filers must submit Form 13F electronically, unless a hardship exemption is available. See Release No. 34-40934 (https://www.sec.gov/rules/final/34-40934.htm). This is reflected in the EDGAR index files, there are 100, 180, 2,165, and 2,346 13F reports filed during 1998Q4, 1999Q1, 1999Q2, and 1999Q3, respectively.

${ }^{26}$ Note that our definition of "filer" is based on whether investors have access to the fund's $13 \mathrm{~F}$ report at the beginning of a quarter, we exclude the last "non-filer" quarter because fund flows during this quarter may or may not be related to the $13 \mathrm{~F}$ report; we exclude the first "filer" quarter because investors typically need two $13 \mathrm{~F}$ reports to reconcile a fund's performance with the changes in its portfolio holdings. Nevertheless, as a robustness check, our results remain when we include these dropped observations (reported in Panel B of Table 7).

${ }^{27}$ There are 676 funds (from 375 management firms) that were $13 \mathrm{~F}$ filers at the start of the sample period ("always-filers"), and 1,823 funds (from 1280 management firms) that never filed $13 \mathrm{~F}$ at any point up to the end of the sample period ("never-filers").
} 
funds form our treatment group, and the remaining funds act as our control group. The sample period is from 1999Q3 to 2016Q3. On average, 32.8\% of observations in each quarter come from $13 \mathrm{~F}$ filers, the figure ranges from $21.3 \%$ at the beginning of the sample period to $36.5 \%$ at the end of the sample period.

\subsubsection{Variable Construction}

To study the smart money effect, we follow the literature (Chevalier and Ellison, 1997; Sirri and Tufano, 1998) and calculate quarterly fund flow as:

$$
\mathrm{Flow}_{i, t}=\frac{\operatorname{AUM}_{i, t}-\mathrm{AUM}_{i, t-3}\left(1+R_{i, t-3: t}\right)}{\mathrm{AUM}_{i, t-3}}
$$

where $\mathrm{Flow}_{i, t}$ is the percent fund flow for fund $i$ at time $t$ over the past three months, $\mathrm{AUM}_{i, t}$ is the assets-under-management of fund $i$ at time $t$, and $R_{i, t-3: t}$ is the net-of-fee return of fund $i$ from time $t-3$ to time $t$.

We evaluate hedge fund performance using monthly net-of-fee returns reported in TASS. In our main analysis, we consider three performance measures: excess return, Fung and Hsieh (2001) seven-factor alpha ("FH7"), and the alpha from the Fung and Hsieh (2001) seven-factor model extended to include the momentum factor ("FH8"). Following Agarwal, Green, and Ren (2018b), we first calculate monthly alphas. Specifically, at the end of each month, we first estimate factor loadings using return observations from the past 24 months (i.e., month $t-23$ to $t$ ) and the following factor model:

$$
\mathrm{r}_{i, t}-\mathrm{r}_{f, t}=\alpha_{i}+\sum_{k=1}^{K} \beta_{i}^{k} \mathrm{~F}_{t}^{k}+\varepsilon_{i, t}
$$

where $r_{i, t}$ is the return of fund $i$ in month $t, r_{f, t}$ is the risk-free rate in month $t, \alpha_{i}$ is the performance measure of fund $i$ over the regression period, $\beta_{i}^{k}$ is the factor loading of the returns of fund $i$ on factor $k$ during the regression period, $F_{t}^{k}$ is the return for factor $k$ in month $t$, and $\varepsilon_{i, t}$ is the error term of fund $i$ in month $t$. Then we calculate alpha based on the 
loadings for month $t+1, t+2$, and $t+3$. Finally we compound these monthly alphas to get quarterly alpha. The Fung and Hsieh (2001) seven factors are: (1) S\&P 500 returns minus the risk-free rate (S\&P 500); (2) Wilshire small-cap 1,750 returns minus Wilshire large-cap 750 returns (SC-LC); (3) changes in the constant maturity yield of the ten-year Treasury bond; (4) changes in the spread of Moodys Baa minus the ten- year Treasury bond; (5) the bond trendfollowing factor (PTFSBD); (6) the currency trendfollowing factor (PTFSFX); and (7) the commodity trendfollowing factor (PTFSCOM). ${ }^{28}$ In the case of FH8 alpha, we obtain the momentum factor from Kenneth R. French's website. ${ }^{29}$ As a robustness check, we also use alternative performance measures, including the market model (CAPM), the Fama and French (1992) three-factor model (FF3), and the Carhart (1997) four-factor model. The results are shown in Panel A of Table 7.

\subsubsection{Summary Statistics}

Table 1 presents the summary statistics of our main sample of hedge funds between 1999Q3 and 2016Q3.

\section{[Table 1 here]}

Flow is the quarterly flow during each calendar quarter. Excess Return, FH' Alpha, and FH8 Alpha are quarterly compounded performance measures. Fund Size is the fund assets under management at each quarter end. Fund Age is the number of months since fund inception. Return Volatility is the return volatility using fund returns between month $t-11$ and $t$. Across all funds and all quarters, the mean (median) fund flow is $-0.27 \%(-0.179 \%)$ with a standard deviation of 18.35; the mean (median) FH7 alpha is 0.766\% (0.522\%) with a standard deviation of 9.417 ; the mean (median) fund size is $\$ 218$ million ( $\$ 54$ million) with a standard deviation of $\$ 825.14$ million; the mean (median) fund age is 104 months (89 months) with a standard deviation of 54.76 months; and the mean (median) return volatility

\footnotetext{
${ }^{28}$ The bond, currency, and commodity trendfollowing factors are directly downloaded from David A. Hsiehs data library: https://faculty.fuqua.duke.edu/ dah7/HFRFData.htm. The other four factors are constructed following the methods in Fung and Hsieh (2001).

${ }^{29}$ See: http://mba.tuck.dartmouth.edu/pages/Faculty/ken.french/data_library.html.
} 
is $11.26 \%(8.52 \%)$ with a standard deviation of $9.92 \%$.

An assumption in the difference-in-difference estimation is that the treatment and control group of funds follow similar patterns prior to the event (i.e., the filing status change from non- $13 \mathrm{~F}$ filer to $13 \mathrm{~F}$ filer). We examine the validity of this parallel trends assumption by comparing the sensitivity of fund returns to fund flows in the 3 quarters prior to the filing status change, for the treatment group compared to the control group.

The treatment sample includes those firms that cross the filing threshold (and start filing 13F) during the sample period from 1999Q3 and 2016Q3. The control sample includes those firms that either never file, or always file, throughout our sample period. For each fund $i$ in the treatment group, we identify the first quarter $q$ that it becomes a $13 \mathrm{~F}$ filer. Next, we match fund $i$ with all funds in the control group at quarter $q$. We then consider the observations for fund $i$ and its control group at quarters $q-1, q-2$, and $q-3$. We then estimate the following cross-sectional regression for the treatment and control groups, for each of the three quarters leading up to the filing event:

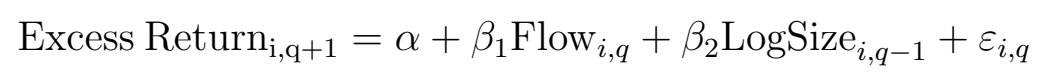

The coefficients $\left(\beta_{1}\right)$ capture the sensitivity of fund return to fund flow prior to the filing status change.

[Figure 1 here]

Figure 1 illustrates that we observe similar patterns in this sensitivity between funds that change their filing status and those in the control group, supporting the existence of parallel trends.

\section{13F Filings and Smart Money}

Following Shi (2017), we study the effect of portfolio disclosure on the informational content of investor flows using (1) a univariate portfolio analysis, and (2) a difference-in-differences 
estimation.

\subsection{Portfolio Sorts}

We first study whether investors make better decisions when investing in 13F-filing funds. We proxy for investor decisions using net fund flows at the fund level. We conjecture that high fund flows reflect investor expectations that returns will be high, and low fund flows reflect expectations that returns will be low. If investors can predict future performance, then the spread in performance between high-flow and low-flow funds will be positive. This spread captures the smart money effect.

If, on average, the spread is higher for $13 \mathrm{~F}$-filing funds, compared to non-13F filers, then this provides evidence that investors, in aggregate, have more information about 13F-filing funds compared to non-13F-filing funds.

Table 2 reports this portfolio-based analysis. At end of each calendar quarter $q$, we consider all hedge funds in our sample. We first sort these funds into two groups based on current filing status: filers and non-filers. Within each group, funds are then sorted into four quartiles based on fund flows in quarter $q$. Value-weighted portfolios are formed within each quartile, and are rebalanced every quarter. We exclude fund-quarters after a fund has stopped filing Form 13F, and we also exclude the two fund-quarters around the switching event (i.e., one quarter before and after the first ever $13 \mathrm{~F}$ filing).

[Table 2 here]

In each panel of Table 2, the first four columns report the monthly performance for the four portfolios sorted on past fund flows. The fifth column, High-Low, presents the spread in average performance between the high-flow and low-flow funds. In each panel, the first row presents the portfolio returns for non-filing funds, the second row presents portfolio returns for filing funds, and the third row presents the difference between filer and non-filer returns.

Panel A presents excess returns, Panel B reports Fung and Hsieh (2001) seven-factor ("FH7") alphas, and Panel C reports alphas based on the Fung and Hsieh (2001) model 
extended to include momentum ("FH8"). In each panel, the bottom right value represents the difference in the high-minus-low spread between filers and non-filers. The difference in the spread is positive and significant (at the $5 \%$ level) in all three specifications. Measured in terms of excess returns, FH7 alpha, and FH8 alpha, the monthly difference in spreads are $34.1 \mathrm{bps}, 30.5 \mathrm{bps}$, and $28.6 \mathrm{bps}$, respectively.

These monthly differences correspond to annual differences of about $4.2 \%$ of excess returns, and $3.7 \%$ of $\mathrm{FH} 7$ alpha. This contrasts with the decrease in average returns documented by Shi (2017) of between $3 \%$ and $4 \%$ of $\mathrm{FH} 7$ alpha after a fund becomes a $13 \mathrm{~F}$ filers. Together, these results suggest that when a fund becomes a $13 \mathrm{~F}$ filer its performance decreases, however some investors may be made better off on net.

\subsection{Difference-in-Differences Estimation - Main Regression}

The portfolio tests provide evidence that some investors earn higher returns after a fund starts filing Form 13F. We next provide evidence of the causal effect of portfolio disclosure on informed investing by studying whether flows become smarter after a fund becomes a filer. We employ a difference-in-differences analysis that compares the difference in the smart money effect before and after disclosure with that of a control group in the same time period.

Conceptually, our approach regresses future performance on hedge fund flows.

$$
\text { Performance }_{\mathrm{i}, \mathrm{q}+\mathrm{t}}=\alpha+\beta \text { Flow }_{\mathrm{i}, \mathrm{q}}+\varepsilon_{i, q}
$$

The smart money effect is captured by the beta in the above regression. It measures whether past investor flows are able to predict future hedge fund performance.

We study how the smart money effect (beta) changes after a hedge fund starts filing Form $13 \mathrm{~F}$. To study how this slope change, we employ a difference-in-differences research design based on Lel and Miller (2015). We use the following panel regression framework with 
fixed-effects:

$$
\text { Performance }_{\mathrm{i}, \mathrm{q}+\mathrm{t}}=\alpha_{i}+\alpha_{q}+\beta \text { Flow }_{\mathrm{i}, \mathrm{q}} \times \text { Treatment }_{\mathrm{i}} \times \text { Post }_{\mathrm{i}, \mathrm{q}}+\text { Controls }_{\mathrm{i}, \mathrm{q}}+\varepsilon_{i, q}
$$

where our treatment group are funds that will file Form $13 \mathrm{~F}$ at some point of the sample, and our post event is whether the fund has already started filing Form 13F. We interact the treatment and post variables with past fund flows, and study whether the smart money effect (beta) between flows and future performance is different for treated funds after the event.

The full regression specification is:

$$
\begin{aligned}
\text { Performance }_{\mathrm{i}, \mathrm{q}+\mathrm{t}}=\alpha_{i} & +\alpha_{q}+\beta_{1} \text { Flow }_{\mathrm{i}, \mathrm{q}} \times 13 \mathrm{~F}_{\mathrm{i}} \times \text { Post }_{\mathrm{i}, \mathrm{q}} \\
& +\beta_{2} 13 \mathrm{~F}_{\mathrm{i}} \times \text { Post }_{\mathrm{i}, \mathrm{q}}+\beta_{3} \text { Flow }_{\mathrm{i}, \mathrm{q}} \times \text { Post }_{\mathrm{i}, \mathrm{q}}+\beta_{4} \text { Flow }_{\mathrm{i}, \mathrm{q}} \times 13 \mathrm{~F}_{\mathrm{i}} \\
& +\beta_{5} \text { Flow }_{\mathrm{i}, \mathrm{q}}+\beta_{6} 13 \mathrm{~F}_{\mathrm{i}}+\beta_{7} \text { Post }_{\mathrm{i}, \mathrm{q}} \\
& +\gamma \text { Controls }_{\mathrm{i}, \mathrm{q}}+\varepsilon_{i, q}
\end{aligned}
$$

Performance f $_{i, q+t}$ is the quarterly compounded performance from quarter $q$ to quarter $q+t$. Performance is measured as (1) excess returns, (2) alpha from the FH7 model, and (3) alpha from the FH8 model. $13 F_{i}$ is an indicator for whether fund $i$ ever files form 13F, and is equivalent to Treatment $i$ in equation 5. Post Trq $_{\text {is }}$ an indicator for whether fund $i$ has filed form $13 \mathrm{~F}$ prior to quarter $q$. Flow $_{i, q}$ is the quarterly fund flow in quarter $q$. Control variables include log fund size (or the linear and quadratic terms of fund size), log fund age, average quarterly fund flows in quarters $q-3, q-2$, and $q-1$, average quarterly returns in the previous four quarters, and the volatility of past 12-month returns. $\alpha_{i}$ are fund-level fixed effects and control for time-invariant omitted fund characteristics, such as manager skill. $\alpha_{q}$ are time fixed effects and account for time-varying factors that affect all funds, such as macroeconomic trends or trends in hedge fund performance. Standard errors are clustered 
at the management company level.

Consistent with Shi (2017), we exclude fund-quarters after the firm stops filing Form 13F. We exclude the fund-quarter before the first filing event, because we are unsure whether flows are due to the time before or after the filing. We also exclude the the first fund-quarter observation after the first filing because we conjecture that the value of portfolio disclosure comes from analyzing portfolio changes. In robustness tests, we demonstrate that our results hold if we do not make these exclusions.

As discussed in Lel and Miller (2015), several terms in this specification are redundant and will be dropped. The $13 F_{i}$ term is equal to one for all funds that ever file form $13 \mathrm{~F}$, in the presence of fund-level fixed effects, this term is redundant. Similarly, the variable Post $t_{i, q}$ is equal to one for all quarters after fund $i$ begins filing form $13 \mathrm{~F}$. That is, this variable is only equal to one for $13 \mathrm{~F}$ filers, and is thus equal to $13 F_{i} \times$ Post $_{i, q}$. We thus drop terms containing the former. We can then rewrite our regression specification as:

$$
\begin{aligned}
\text { Performance }_{\mathrm{i}, \mathrm{q}+\mathrm{t}}=\alpha_{i} & +\alpha_{q}+\beta_{1} \text { Flow }_{\mathrm{i}, \mathrm{q}} \times 13 \mathrm{~F}_{\mathrm{i}} \times \text { Post }_{\mathrm{i}, \mathrm{q}} \\
& +\beta_{2} 13 \mathrm{~F}_{\mathrm{i}} \times \text { Post }_{\mathrm{i}, \mathrm{q}}+\beta_{4} \text { Flow }_{\mathrm{i}, \mathrm{q}} \times 13 \mathrm{~F}_{\mathrm{i}}+\beta_{5} \text { Flow }_{\mathrm{i}, \mathrm{q}} \\
& +\gamma \text { Controls }_{\mathrm{i}, \mathrm{q}}+\varepsilon_{i, q}
\end{aligned}
$$

This specification allows us to study how the smart-money effect changes after a fund becomes a filer (captured by $\beta_{1}$ ), controlling for the fact that the smart money effect might be different for filers compared to non-filers. Throughout our regression analyses, the variables are winsorized at $0.5 \%$ and $99.5 \%$ level to remove the influence of outliers.

[Table 3 here]

Table 3 reports the regression results for equation (7) using performance measures in quarter $q+1$. The dependent variable is excess returns in Columns 1, 2, and 3; FH7 alpha is Columns 4, 5, and 6; and FH8 alpha in Columns 7, 8, and 9. Columns 4, 6, and 9 report 
the full specification from equation 7 . In each case, the coefficient on our variable of interest, i.e., the beta on Flow $\times 13 F \times$ Post, is positive and significant at the $5 \%$ level. After a fund starts filing Form 13F, the increase in the smart money effect is $0.025,0.019$, and 0.023 in the excess return, FH7 alpha, and FH8 alpha specifications, respectively. The interquartile range of flows (from Table 1) is 8.69, thus the impact on annual performance for an interquartile increase in flows for filers vs. non-filers is $87 \mathrm{bps}, 66 \mathrm{bps}$, and 80 bps for excess returns, FH7 alpha, and FH8 alpha respectively.

These economic magnitudes are smaller than the estimates from the portfolio analysis, but are still positive and significant. The portfolio analysis was conducted with valueweighted returns, and thus may better capture the dollar increase in value.

\subsection{Difference-in-Differences Estimation - RDD}

The diff-in-diff analysis of the previous section uses the entire (cleaned) time-series of data available for each fund. One issue is that funds above the threshold might simply be better funds. For example, they might be more forthcoming with information, which helps investors make better decisions. Funds far from the cutoff may be materially different from funds close to the cutoff, and this difference may not be fully captured by covariates.

We use a regression discontinuity design (RDD) to limit the unintended effect of these large management companies. To ensure that we are not simply capturing the effect of total value of $13(\mathrm{f})$ securities at the management company (as opposed to the effect of mandatory portfolio disclosure), we repeat our baseline regression using only funds managed by management companies around the $\$ 100$ million threshold. Since we cannot observe the value of $13(\mathrm{f})$ securities for non-filers, we use the following two methods to restrict our sample: (i) for funds that experience a filing status switch (i.e., from non-filing to filing), we restrict the sample to those fund-quarter observations around the filing status change. In practice, we restrict the sample to the four-year window centered around its first ever $13 \mathrm{~F}$ 
filing; in doing so, the total value of $13(\mathrm{f})$ securities should be around $\$ 100$ million. ${ }^{30}$ and (ii) following Shi (2017), we restrict the sample based on the fund company AUM reported in TASS. Specifically, for our full regression sample, we only keep fund-quarter observations where the TASS company AUMs are between 50 million and 300 million.

[Table 4 here]

Table 4 reports the RDD analysis. We repeat the baseline regression analysis (equation 7) for subsamples (i) and (ii). Subsample (i) is reported in Columns 1, 2, and 3, and subsample (ii) is reported in Columns 4, 5, and 6. Here we find that our coefficient of interest increases in the RDD analysis across all specifications. For example, Column 9 of Table 3 corresponds to Column 6 of Table 4 . Here we see the coefficient increases from 0.023 to 0.048 . In terms of economic magnitude, an interquartile increase in flows leads to a 167 bps increase in FH8 alpha (for filers vs. non-filers), this compares to 80 bps increase reported in the baseline specification.

\subsection{Placebo Test}

Another issue with our identification strategy is that better firms may endogenously cross the threshold. Better firms attract more capital, and will be more likely to cross the threshold. Even in the RDD setting, we still might have a difference in quality in firms above and below the threshold.

We address this issue by conducting a placebo test. We redo the main analysis of equation 7 using only FoFs. FoFs are hedge funds that invest in other hedge funds. They typically do not invest in 13(f) securities, and as such, the information revealed on their parent company's $13 \mathrm{~F}$ filing should be minimal.

[Table 5 here]

Table 5 reports the estimates of the placebo regressions. This repeats the analysis pre-

\footnotetext{
${ }^{30}$ Note that since we only use funds that have ever changed filing status, the term $13 F$ would always be 1, therefore Flow $\times 13 F$ would take the same value as Flow. In light of this, we drop the term Flow $\times 13 F$ when reporting the regression results.
} 
sented in Table 3, except only using FoFs. Here, the coefficient on our variable of interest $($ Flow $\times 13 F \times$ Post $)$ is sometimes positive, sometimes negative, but never significantly different from zero. Thus, this provides us with evidence that our results are results are not spurious.

\subsection{Difference-in-Differences Estimation - Persistence}

Our results provide evidence that the smartness of money increases after a fund starts filing Form 13F. However, our outcome variable so far is short-term - it is only one quarter into the future. The average redemption period for a hedge fund is about 100 days (Getmansky et al., 2015b), which is longer than a quarter. In this section, we test the persistence of the smart money effect, to see whether the effect reverses before investors can redeem.

[Table 6 here]

We repeat the baseline specification (equation 7 ) but replace performance one quarter into the future with performance two quarters, three quarters, and four quarters into the future. The results are presented in Table 6 . Here, we find some evidence that smart money is persistent. In particular, it seems the $13 \mathrm{~F}$-induced smart money effect is persistent at a horizon of two quarters when performance is measured in terms of FH7 alpha and FH8 alpha.

More importantly, we do not find evidence that the $13 \mathrm{~F}$-induced smart money effect reverses in the year following the investment decision.

\subsection{Robustness}

We next investigate the robustness of our results through a series of tests. The first set of tests studies alternative measures of performance and alternative samples. The second set of tests expand the set of control variables. 


\subsubsection{Alternative Measures and Samples}

Table 7 reports the results from robustness tests that use alternative measures of performance and alternative samples of the data.

[Table 7 here]

Columns 1, 2, and 3 estimate our main regression specification (equation 7) using CAPM alpha, Fama and French (1992) 3-factor alpha, and Carhart (1997) 4-factor alpha, respectively. The effect of these alphas should be absorbed in our specification by the FH7 and FH8 alpha. Indeed, we see that while the main effect decreases slightly, it remains positive and significant.

Columns 4, 5, and 6 report regressions results for the full sample. Recall, in our main specification we drop fund-quarter observations (i) after the firm stops filing Form 13F, and (ii) in the quarter directly before and after the fund becomes a filer. In these tests, we include those dropped observations. We find that the main effect remains positive and significant.

We next limit our analysis to the subset of firms that eventually file Form 13F. This addresses the concern that the control group might consist of funds that are fundamentally different from the firms that become filers. Columns 7, 8, and 9 repeat our main analysis (equation 7) using only fund-quarters observations from funds that experience filing status change during the sample period (i.e., from non- $13 \mathrm{~F}$ filer to $13 \mathrm{~F}$ filer). We further restrict the sample so that a given fund has at least one observation before- and one observation afterthe status change. In this regression, the variable $13 F_{i}$ is equal to one for all observations, thus the term Flow $\times 13 F$ drops out of the regression. The baseline result remains positive and significant in this subsample. In Columns 10, 11, and 12, we estimate our baseline regression model using only funds that never filed $13 \mathrm{~F}$ as control group. This is similar to the restriction imposed by Lel and Miller (2015) on their sample. 


\subsubsection{Additional Controls}

We next extend the baseline analysis to include additional control variables. We include (i) observable fund-level variables, and (ii) unobservable company-level fixed effects. Our baseline specification includes fund-level fixed effects, thus we expect the additional fundlevel controls will have a minimal impact.

Table 8 reports the results from extending our analysis to include observable fund-level characteristics, and company fixed-effects (to control for unobservable company characteristics).

[Table 8 here]

In Columns 1, 2, and 3, we estimate our baseline regression model including time-invariant fund-level characteristics. The additional controls variables include the following: redemption notice period, measured in units of 30 days (RedemptionNotice); lockup period (LockUp); management fee (MgmtFee); incentive fee (IncentiveFee); the log of one plus minimum investment (MinInvestment); indicator variables for: whether personal capital is committed (PersonalCapital); whether there is a high water mark provision $(H W M)$; whether the fund uses leverage (Leveraged); and whether the fund is offshore (Offshore). Because these controls are fund-level time-invariant, we include style fixed-effects instead of fund fixed-effects; also note that in absence of fund fixed-effects, the stand alone term $13 F$ is added back to the regression specifications. Here we see that after controlling for observable fund-level characteristics, the coefficient on the triple-interaction term remains positive and significant.

We next include company fixed-effects to control for unobservable time-invariant properties that may affect the funds. In columns 4, 5, and 6, we estimate the regression model with firm controls and company fixed-effects. Note that after including company fixed-effects, the stand-alone term $13 F$ is again redundant. Here we again see that the coefficient on the triple-interaction term remains positive and significant. 


\section{Cross-Sectional Analysis}

To shed light on the economic mechanisms that drive our results, we next explore the rich cross-sectional heterogeneity among sample hedge funds. We look at how variation in the informational content and usefulness of $13 \mathrm{~F}$ filings relates to the smart money effect. We find that the smart money effect increases when information is more precise, when it can be used more freely, and when investors pay more attention to it.

These results also provide evidence against the alternative story that there exists a smarter set of investors who are restricted to investing only in $13 \mathrm{~F}$-filing funds. If this were the case, then we should expect to see an increase in smart money, even when $13 \mathrm{~F}$ filings do not provide much incremental information.

\subsection{Disclosure Fraction}

Our first set of tests study the informational content of $13 \mathrm{~F}$ filings. Form $13 \mathrm{~F}$ is filed at the company level. It reports the aggregate long-positions of all the firm's hedge fund and mutual fund products. Our analysis, however, is conducted at the fund level. For a given fund, if it is the only fund offered by its management company, then the company's $13 \mathrm{~F}$ filing will reveal the fund's entire long position. If, on the other hand, the fund belongs to a mutli-fund company, then the fund's long positions will be obfuscated with those of its sibling funds. Thus, we expect the informational content of a $13 \mathrm{~F}$ filing should be higher when the fund comes from a single-fund family, as opposed to a mutli-fund family.

We expect to find stronger results if investors have more precise information. We split the sample in the following three ways: (i) based on whether the fund is from a single-fund company or a multi-fund company; (ii) based on whether a fund is the largest fund within a fund company; and (iii) based on whether the proportion of its portfolio reveled in $13 \mathrm{~F}$ is above or below the cross-sectional median. ${ }^{31}$

\footnotetext{
${ }^{31}$ Specifically, for each quarter, we split the sample based on the ratio of fund assets to the total assets of its management company (i.e., fund AUM divided by company AUM).
} 
[Table 9 here]

Table 9 reports the results of these cross-sectional tests. The dependent variable (performance) is measured as the quarterly FH7 alpha. Columns 1 and 2 report the results of method (i); Columns 3 and 4 report the results of method (ii); and Columns 5 and 6 report the results of method (iii). Here, we see that the effect is driven by the funds with more precise information in $13 \mathrm{~F}$. In each of the odd-numbered columns, the coefficient on the triple interaction term is positive and significant; in each of the even-numbered columns, the coefficient is positive but insignificant. These results demonstrate that the smart money effect is stronger when investors have more precise information.

\subsection{Mobility of Capital}

Our next set of tests study whether the smart money effect is related to the ease of which an investor can get in and out of a fund. The information contained in Form $13 \mathrm{~F}$ is only of value if investors can actually use it. If there are restrictions on redemptions or subscriptions, then we expect the information will be less useful. That is, we expect the smart money effect will increase by more when money can freely enter or exit a fund.

To investigate this, we split the sample based on the following fund characteristics: (i) whether a fund has lock-up provision; (ii) the redemption frequency; (iii) the length of the redemption notice period; and (iv) the subscription frequency. ${ }^{32}$

[Table 10 here]

Table 10 reports the results of the mobility tests. The dependent variable (performance) is measured as the quarterly FH7 alpha. Columns 1 and 2 report the results of method (i); Columns 3 and 4 report the results of method (ii); Columns 5 and 6 report the results of method (iii); and Columns 7 and 8 report the results of method (iv). The odd-numbered columns represent the subsample of firms with less restrictions on the movement of investor

\footnotetext{
${ }^{32}$ Since our main analysis is conducted at a quarterly frequency, we split the sample around the 3-month mark (for ii, iii, and iv). Funds with a frequency or period less (greater) than three months are grouped into the "short"( "long") bin.
} 
capital. The coefficient on the triple interaction term is positive and significant across all the odd-numbered columns, while positive and insignificant across the even-numbered columns (those with more restrictions on investor capital). These results demonstrate that money is smarter when information can be used more freely.

\subsection{Investor Attention}

We next investigate cross-sectional differences in how investors access information. We conjecture that when more investors view $13 \mathrm{~F}$ filings, the smart money effect will be stronger. We use the EDGAR log files to measure when potential investors access $13 \mathrm{~F}$ filings. ${ }^{33}$ One caveat is that this measure will also pick up the activity of copycat traders. This introduces noise to our measure, but because copycat trading is not related to the smart money effect, this noise should bias us away from finding a relationship between attention and smart money.

We split the sample based on investor attention. ${ }^{34}$ For a given fund-quarter, we calculate the number of downloads of $13 \mathrm{~F}$ reports that are available at the beginning of the quarter as the proportion of requests made on all available $13 \mathrm{~F}$ reports in EDGAR during the same quarter. ${ }^{35}$ Then, for a given fund, we average the measure across all quarters to get the fund-level investor attention measure. Finally, we split the sample based on the median value of investor attention.

\footnotetext{
${ }^{33}$ Numerous studies have used this data set to measure investor attention; for example, see: Drake, Roulstone, and Thornock (2015), Lee, Ma, and Wang (2015), and Li and Sun (2018). The EDGAR log files data set can be found here: https://www.sec.gov/dera/data/edgar-log-file-data-set.html.

${ }^{34}$ Because "Non-filers" will automatically have zero downloads, we only include those funds that switch from non-13F filer to $13 \mathrm{~F}$ filer in our regression sample.

${ }^{35}$ We follow the literature to identify and drop "robot" downloads from the raw EDGAR log file. Specifically, we follow the procedure described in Li and Sun (2018): First, following Lee et al. (2015), we exclude the searching records of those users who download more than 50 unique firms filings in one day. The user is identified by their unique IP address. Second, following Ryans (2017) and Drake et al. (2015), we remove $\log$ records that reference an index (i.e, $i d x=1$ ), as index pages only provide the links to filings rather than the actual filing data. Third, following Ryans (2017), we keep the request records with successful document delivery (i.e., code $=200$ ). We then further exclude the search records of users who make more than 25 filing requests per minute or more than 500 requests per day, or with more than three unique CIKs searching per minute. Finally, we only keep one search record for a specific filing (unique accession number) to each user in a given day.
} 
[Table 11 here]

Table 11 reports the results of the investor attention tests. The dependent variable (performance) is measured as the quarterly FH7 alpha. Panel A reports the subsample regression results described above. In Panel B, we use all EDGAR filings instead of only 13F filings (as denominator) when calculating the fund-quarter investor attention. In Panel $\mathrm{C}$ and Panel D, we repeat the analyses in Panel A and Panel B using the number of unique IP addresses instead of the number of downloads.

Across all four panels, the coefficient of interest (on Flow $\times 13 F \times$ Post) is positive and significant for the high investor attention subsample (the odd-numbered columns). For the low investor attention subsample is positive but not significant. These results provide evidence that there is investor-relevant information contained in $13 \mathrm{~F}$ filings, and that when investors in aggregate access this information they make more informed investment decisions.

Our three sets of tests demonstrate that the smart money effect is stronger when investors have more precise information, when they are less restricted in using this information, and when more investors access information. This is consistent with investors using portfolio disclosure to make more informed allocation decisions. It is inconsistent with the story that smarter investors choose 13F-filing funds, because then cross-sectional differences in information should not matter.

\section{Holdings-Based Analysis}

As mentioned above, one concern is that our findings may be driven by $13 \mathrm{~F}$-filing funds having a different, more sophisticated investor clientele than that of non-filing funds. To ensure that our results are not due to smart investors purchasing and selling $13 \mathrm{~F}$-filing funds, rather than $13 \mathrm{~F}$ filings making investors smart, we employ investor-level, hedge fund portfolios, available for registered FoFs, to explore the investment decisions of a given investor within the universe of $13 \mathrm{~F}$-filing versus non-filing hedge funds. Conceptually, this analysis 
can be viewed as comparing the smart money effect for $13 \mathrm{~F}$-filing versus non-filing hedge funds - after controlling for investor fixed effects.

Following Gao et al. (2019), we first use answers in Form N-SAR filings to identify potential FoFs among all registered investment companies. ${ }^{36}$ This procedure yields a sample of 496 potential FoFs. Next, we use holdings data reported in forms N-CSR, N-CSRS, and N-Q to exclude funds that primarily hold assets other than hedge funds. In the process, we also drop funds that fail to raise capital (and thus report zero holdings throughout their lifetime). Finally, we identify funds with master-feeder structures so that only master funds are included in our sample. ${ }^{37}$ The final sample consists of 127 FoFs covering a sample period from 2004Q3 to 2016Q4..$^{38}$

We hand collect quarterly holdings data from Form N-CSR, N-CSRS, and N-Q filings for all registered FoFs in our final sample. We then match each portfolio hedge fund with the list of hedge fund names in TASS and Form ADV. ${ }^{39}$ Overall, we are able to match $79.06 \%$ of the portfolio hedge funds. ${ }^{40}$ To determine whether a portfolio hedge fund-quarter observation is "filer" or "non-filer", we follow the same procedure described in section 2.2."

[Table 12 here]

Table 12 presents the summary statistics of our sample of FoFs. Panel A, B, and C reports the statistics at the end of 2004, 2010, and 2016, respectively. At the end of 2010, for example, our sample consists of 46 FoFs; the mean (median) FoF size is $\$ 392$ million (\$119 million). On average, a FoF holds 31 hedge funds, of which 17 are "filer" hedge funds and 9 are "non-filer" hedge funds; ${ }^{42}$ and a FoF invests $65 \%$ and $23 \%$ of its total assets in "filer"

\footnotetext{
${ }^{36}$ Specifically, we first identify closed-end funds using Item 27 , as FoFs commonly register as closed-end funds. We then filter funds with minimum initial investment requirements using Item 61 of the filing.

${ }^{37}$ This is because that feeder funds normally invest $100 \%$ in their master funds.

${ }^{38}$ Our sample starts in 2004 because registered investment companies are required to file quarterly holdings starting from 2004.

${ }^{39}$ In Section 7.B.(1) of Form ADV, registered investment advisers are required to report all private funds that they advise.

${ }^{40}$ Among all portfolio hedge funds, $23.64 \%$ have matches in TASS and $74.96 \%$ have matches in Form ADV.

${ }^{41}$ For funds matched with Form ADV, we utilize the "legal name" reported in Item 1.A of Form ADV and check whether it is among companies that have filed at least one $13 \mathrm{~F}$ report.

${ }^{42}$ For the remaining 5 portfolio hedge funds that cannot be matched with either TASS or Form ADV, we do not know their management firms/advisers and therefore are not categorized as either "filer" or "non-filer".
} 
hedge funds and "non-filer" hedge funds, respectively.

Following Aiken et al. (2013), we use the following formula to generate quarterly hedge fund returns:

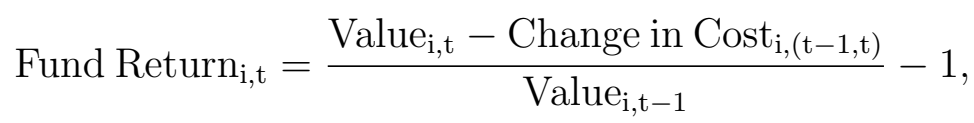

where Value is the current value of the underlying hedge fund $i$, and Change in Cost is the change in cost basis in the underlying hedge fund $i$ between two adjacent quarter-ends. In this analysis, we focus exclusively on those returns in which cost basis does not change. ${ }^{43}$ Multiple FoFs may hold the same underlying hedge fund at the same quarter-end. In case we cannot calculate return for a given hedge fund position (due to change in cost basis, or cost is missing), we use the cross-sectional average returns of the same hedge fund held by all other FoFs in the same quarter, as long as the spread between the minimum and maximum returns is no more than $1 \%{ }^{44}$ Finally, all returns are winsorized at $1 \%$ and $99 \%$ level to remove the influence of outliers.

\subsection{Holdings-Based Analysis: Full Sample}

We use a standard holdings-based analysis of the sort used in Coval and Moskowitz (2001) and Cohen, Frazzini, and Malloy (2008), but we look at the performance of FoFs' 13F-filing hedge fund holdings (rather than local or connected holdings) compared to their non-filing hedge fund holdings. Specifically, at the end of each calendar quarter, we assign hedge funds in each FoF's portfolio to one of two portfolios: 13F-filing or non-filing. We then compute the quarterly returns on 13F-filing and non-filing holdings over the next quarter, assuming that FoFs did not change their holdings between quarter-ends. Portfolios are rebalanced every calendar quarter, and within a given FoF-quarter, hedge funds are value-weighted by their value at the end of the previous quarter (i.e., 13F-filing hedge funds are value-weighted

\footnotetext{
${ }^{43}$ As noted in Aiken et al. (2013), there are discrepancies in how each FoF reports changes in cost. Moreover, changes in cost require placing strong assumptions on the timing of cost changes throughout the quarter.

${ }^{44}$ We use the matches with TASS and Form ADV to track the same hedge fund across different FoFs.
} 
in the FoF's 13F-filing portfolio, and non-filing hedge funds are value-weighted in the FoF's non-filing portfolio); we then calculate the spread between the two value-weighted returns. Finally, we average calendar time portfolios across FoFs and quarters, with standard errors clustered at various levels. ${ }^{45}$ For a given FoF-quarter observation to be included in the analysis, we require that (1) at least $50 \%$ of its holdings can be matched with TASS or Form ADV (and therefore we can determine their filing statuses), (2) its 13F-filing portfolio contains at least one 13F-filing hedge fund with valid returns, and (3) its non-filing portfolio contains at least one non-filing hedge fund with valid returns. The final sample consists of 2,084 FoF-quarter observations from 117 FoFs, spanning 49 quarters.

In addition to examining portfolios of the FoF's holdings, we also compute returns on the 13F-filing hedge funds that FoFs choose not to hold. Using the similar portfolio construction approach as before, we compute equal-weighted returns on portfolios of $13 \mathrm{~F}$-filing hedge funds that FoFs choose not to hold. ${ }^{46}$ For a given FoF-quarter observation to be included in the analysis, we require that (1) at least $50 \%$ of its holdings can be matched with TASS or Form ADV (and therefore we can determine their filing statuses), (2) its 13F-filing held portfolio contains at least one 13F-filing hedge fund with valid returns, and (3) its 13F-filing not held portfolio contains at least one 13-filing hedge fund with valid returns. The final sample consists of 2,355 FoF-quarter observations from 122 FoFs, spanning 49 quarters.

[Table 13 here]

Table 13 reports our holdings-based results using entire sample of hedge funds. Panel A presents the comparison between $13 \mathrm{~F}$-filing portfolio and non-filing portfolio. On average, a FoF holds 11.2 "filer" hedge funds and 5.3 "non-filer" hedge funds. The results show that 13F-filing holdings earn 1.59\% per quarter in raw returns and non-filing holdings earn $1.35 \%$ per quarter in raw returns. The spread of the long-short portfolio is $0.23 \%$ per quarter (or $0.92 \%$ per year), and is statistically significant at $10 \%$ level even with standard errors

\footnotetext{
${ }^{45}$ We use the following clustering methods: (1) no clustering; (2) clustered by quarter; (3) clustered by FoF; and (4) double-clustered by FoF and quarter.

${ }^{46}$ We use equal-weighted here because we do not observe AUMs of underlying hedge funds.
} 
double-clustered by FoF and quarter. Panel B presents the comparison between 13F-filing held portfolio and 13F-filing not held portfolio. 13F-filing held portfolio earn $1.46 \%$ per quarter in raw returns and $13 \mathrm{~F}$-filing not held portfolio earn $1.25 \%$ per quarter in raw returns. The spread of the long-short portfolio is $0.21 \%$ per quarter (or $0.84 \%$ per year), and is statistically significant at $5 \%$ level even with standard errors double-clustered by FoF and quarter. Our results lend support to the hypothesis that investors have comparative advantages in selecting 13F-filing hedge funds.

\subsection{Holdings-Based Analysis: Non-Local Funds}

To further shed light on the role of $13 \mathrm{~F}$ filings on investor's investment decision, we look at how variation in the informational advantages relates to the smart money effect. Prior research suggests that professional money managers have local preference and local informational advantages (Coval and Moskowitz, 2001; Teo, 2009; Sialm et al., 2019). Since geographic proximity facilitates the information production, the monitoring, and the access to fund managers, $13 \mathrm{~F}$ reports should be more valuable to hedge fund investors (e.g., FoFs) when choosing among non-local hedge funds. Therefore, we expect to find more pronounced results when using a subset of hedge funds that are non-local to the FoFs. Following Sialm et al. (2019), we define a fund's location as the Metropolitan Statistical Area (MSA). We first obtain FoF's zip code and state information from header information reported in Form N-CSR, N-CSRS, and N-Q filings. Using the state/zip code information, we then merge it with the Metropolitan Areas and Components data defined by the Office of Management and Budget (OMB) as of $2013 .{ }^{47}$ For each underlying hedge fund that is matched with TASS or Form ADV, we obtain zip code and state information from TASS (zip code and state of its management firm) and Form ADV (zip code and state reported in Item 1.F.1) and merge it with MSA data from OMB. An underlying hedge fund is defined as non-local if its MSA

\footnotetext{
${ }^{47}$ The Metropolitan Areas and Components data is updated every 10 years, and the 2013 version is the latest release at the time of our study.
} 
is different from that of the FoF. ${ }^{48}$ We then repeat our holdings-based analysis using the subset of the non-local hedge funds. The inclusion requirement is similar. For example, in the $13 \mathrm{~F}$-filing portfolio versus non-filing portfolio analysis, we require a FoF-quarter to have (1) at least $50 \%$ of its holdings can be matched with TASS or Form ADV (and therefore we can determine their filing statuses and geographical information), (2) its 13F-filing portfolio contains at least one non-local 13F-filing hedge fund with valid returns, and (3) its non-filing portfolio contains at least one non-local non-filing hedge fund with valid returns.

[Table 14 here]

Table 14 reports our holdings-based results using the subset of non-local portfolio hedge funds. Panel A presents the comparison between 13F-filing portfolio and non-filing portfolio. The final sample consists of 1,952 FoF-quarter observations from 116 FoFs, spanning 49 quarters. On average, a FoF holds 8.6 non-local "filer" hedge funds and 4.6 non-local "non-filer" hedge funds. The results show that $13 \mathrm{~F}$-filing holdings earn $1.52 \%$ per quarter in raw returns and non-filing holdings earn $1.17 \%$ per quarter in raw returns. The spread of the long-short portfolio is $0.35 \%$ per quarter (or $1.4 \%$ per year), and is statistically significant at 5\% level even with standard errors double-clustered by FoF and quarter. Panel B presents the comparison between non-local 13F-filing held portfolio and non-local 13F-filing not held portfolio. The final sample consists of 2,308 FoF-quarter observations from 122 FoFs, spanning 49 quarters. 13F-filing held portfolio earn $1.45 \%$ per quarter in raw returns and $13 \mathrm{~F}$-filing not held portfolio earn $1.2 \%$ per quarter in raw returns. The spread of the long-short portfolio is $0.25 \%$ per quarter (or $1 \%$ per year), and is statistically significant at $1 \%$ level even with standard errors double-clustered by FoF and quarter. The magnitude from both tests are larger than the results in section 5.1. The results suggest that $13 \mathrm{~F}$ reports are more useful when investor's informational advantage regarding the underlying hedge fund is comparatively weak. Overall, our holdings-based analysis addresses the concern that our results are driven by funds with different filing statuses having different investor clienteles.

\footnotetext{
${ }^{48}$ All the FoFs in our sample are located in the U.S., however, some portfolio hedge funds are located outside the U.S.; we categorize all non-U.S. portfolio hedge funds as non-local.
} 


\section{Conclusion}

Hedge fund manager actions are largely opaque. A large information asymmetry exists between investors and fund managers. The Rule 13(f)-1 filing requirement divulges funds' proprietary holdings to the public, and while this has been shown to negatively impact fund returns, we study whether it also allows investors to better evaluate and select hedge funds.

We examine whether investors' purchasing and selling decisions, captured by hedge fund flows, are better able to predict hedge funds' future performance (i.e., whether the smart money effect is stronger) for 13F-filing hedge funds than for non-filing hedge funds. We find evidence that investor flows are indeed smarter for 13F-filing funds. In particular, we investigate cross-sectional differences in the precision, usefulness, and access of information, and provide evidence that the information contained in Form 13F improves investor selection ability. Finally, we use quarterly FoFs' holdings and show that hedge fund investors' holdings of 13F-filers outperform their non-filer holdings.

By providing comprehensive evidence that portfolio disclosure makes investors smarter in selecting money managers, in a setting where managers' actions are otherwise hard to monitor, we highlight the benefits of mandatory portfolio disclosure and thus provide policy makers with a more balanced understanding of the impact of Form $13 \mathrm{~F}$ disclosure. 


\section{References}

Agarwal, Vikas, George O Aragon, and Zhen Shi, 2018a, Liquidity transformation and financial fragility: Evidence from funds of hedge funds, Journal of Financial and Quantitative Analysis 1-58.

Agarwal, Vikas, T Clifton Green, and Honglin Ren, 2018b, Alpha or beta in the eye of the beholder: What drives hedge fund flows?, Journal of Financial Economics 127, 417-434.

Agarwal, Vikas, Wei Jiang, Yuehua Tang, and Baozhong Yang, 2013, Uncovering hedge fund skill from the portfolio holdings they hide, The Journal of Finance 68, 739-783.

Agarwal, Vikas, Stefan Ruenzi, and Florian Weigert, 2018c, Unobserved performance of hedge funds, Available at SSRN, Working Paper.

Aggarwal, Rajesh K, and Philippe Jorion, 2010, The performance of emerging hedge funds and managers, Journal of Financial Economics 96, 238-256.

Aiken, Adam L, Christopher P Clifford, and Jesse Ellis, 2013, Out of the dark: Hedge fund reporting biases and commercial databases, Review of Financial Studies 26, 208-243.

Aiken, Adam L, Christopher P Clifford, and Jesse Ellis, 2015, The value of funds of hedge funds: Evidence from their holdings, Management Science 61, 2415-2429.

Aragon, George O, Michael Hertzel, and Zhen Shi, 2013, Why do hedge funds avoid disclosure? evidence from confidential 13f filings, Journal of Financial and Quantitative Analysis 48, 1499-1518.

Baquero, Guillermo, and Marno Verbeek, 2005, A portrait of hedge fund investors: Flows, performance and smart money, ERIM Report Series Reference No. ERS-2005-068-F\&A.

Bhardwaj, Geetesh, Gary B Gorton, and K Geert Rouwenhorst, 2014, Fooling some of the people all of the time: The inefficient performance and persistence of commodity trading advisors, Review of Financial Studies 27, 3099-3132.

Brown, Stephen J, and Christopher Schwarz, 2013, Do market participants care about portfolio disclosure? evidence from hedge funds $13 \mathrm{f}$ filings, Working Paper.

Cao, Sean, Kai Du, Baozhong Yang, and Liang Zhang, 2018, Copycatting and public disclosure: Direct evidence from peer companies digital footprints, Available at SSRN 3280744, Working Paper.

Carhart, Mark M, 1997, On persistence in mutual fund performance, The Journal of Finance $52,57-82$.

Chevalier, Judith, and Glenn Ellison, 1997, Risk taking by mutual funds as a response to incentives, The Journal of Political Economy 105, 1167-1200.

Cochrane, John H, 2014, Challenges for cost-benefit analysis of financial regulation, The Journal of Legal Studies 43, S63-S105. 
Cohen, Lauren, Andrea Frazzini, and Christopher Malloy, 2008, The small world of investing: Board connections and mutual fund returns, Journal of Political Economy 116, 951-979.

Coval, Joshua D, and Tobias J Moskowitz, 2001, The geography of investment: Informed trading and asset prices, Journal of Political Economy 109, 811-841.

Cremers, KJ Martijn, and Antti Petajisto, 2009, How active is your fund manager? a new measure that predicts performance, Review of Financial Studies 22, 3329-3365.

Drake, Michael S, Darren T Roulstone, and Jacob R Thornock, 2015, The determinants and consequences of information acquisition via edgar, Contemporary Accounting Research 32, $1128-1161$.

Fama, Eugene F, and Kenneth R French, 1992, The cross-section of expected stock returns, The Journal of Finance 47, 427-465.

Fung, William, and David A Hsieh, 2001, The risk in hedge fund strategies: Theory and evidence from trend followers, The Review of Financial Studies 14, 313-341.

Gao, Chao, Timothy D Haight, and Chengdong Yin, 2019, Fund selection, style allocation, and active management abilities: Evidence from funds of hedge funds holdings, Financial Management 1-25.

Gârleanu, Nicolae, and Lasse Heje Pedersen, 2018, Efficiently inefficient markets for assets and asset management, The Journal of Finance 73, 1663-1712.

Getmansky, Mila, Peter A. Lee, and Andrew W. Lo, 2015a, Hedge funds: A dynamic industry in transition, Working Paper 21449, National Bureau of Economic Research.

Getmansky, Mila, Bing Liang, Christopher Schwarz, and Russ Wermers, 2015b, Share restrictions and investor flows in the hedge fund industry, Available at SSRN, Working Paper.

Gruber, Martin J, 1996, Another puzzle: The growth in actively managed mutual funds, The Journal of Finance 51, 783-810.

Jayaraman, Sudarshan, and Joanna Shuang Wu, 2018, Is silence golden? real effects of mandatory disclosure, The Review of Financial Studies 32, 2225-2259.

Jensen, Michael C, 1976, The financiers: the world of the great Wall Street investment banking houses (Weybright and Talley).

Kacperczyk, Marcin, Clemens Sialm, and Lu Zheng, 2005, On the industry concentration of actively managed equity mutual funds, The Journal of Finance 60, 1983-2011.

Kacperczyk, Marcin, Clemens Sialm, and Lu Zheng, 2008, Unobserved actions of mutual funds, The Review of Financial Studies 21, 2379-2416. 
Lee, Charles MC, Paul Ma, and Charles CY Wang, 2015, Search-based peer firms: Aggregating investor perceptions through internet co-searches, Journal of Financial Economics $116,410-431$.

Lel, Ugur, and Darius P Miller, 2015, Does takeover activity cause managerial discipline? evidence from international m\&a laws, The Review of Financial Studies 28, 1588-1622.

Lemke, Thomas P, and Gerald T Lins, 1987, Disclosure of equity holdings by institutional investment managers: An analysis of section 13 (f) of the securities exchange act of 1934, The Business Lawyer 43, 93-119.

Leuz, Christian, and Peter D Wysocki, 2016, The economics of disclosure and financial reporting regulation: Evidence and suggestions for future research, Journal of Accounting Research 54, 525-622.

Li, Frank Weikai, and Chengzhu Sun, 2018, Information acquisition and expected returns: Evidence from edgar search traffic, Working Paper.

Ozik, Gideon, and Ronnie Sadka, 2015, Skin in the game versus skimming the game: Governance, share restrictions, and insider flows, Journal of Financial and Quantitative Analysis 50, 1293-1319.

Ryans, James, 2017, Using the edgar log file data set, Available at SSRN 2913612, Working Paper.

Sapp, Travis, and Ashish Tiwari, 2004, Does stock return momentum explain the smart money effect?, The Journal of Finance 59, 2605-2622.

Shi, Zhen, 2017, The impact of portfolio disclosure on hedge fund performance, Journal of Financial Economics 126, 36-53.

Shiller, Robert J, 2013, Finance and the good society (Princeton University Press).

Sialm, Clemens, Zheng Sun, and Lu Zheng, 2019, Home bias and local contagion: Evidence from funds of hedge funds, Review of Financial Studies, Forthcoming .

Sirri, Erik R, and Peter Tufano, 1998, Costly search and mutual fund flows, The Journal of Finance 53, 1589-1622.

Teo, Melvyn, 2009, The geography of hedge funds, The Review of Financial Studies 22, $3531-3561$.

Zheng, Lu, 1999, Is money smart? a study of mutual fund investors' fund selection ability, The Journal of Finance 54, 901-933.

Zingales, Luigi, 2015, Presidential address: Does finance benefit society?, The Journal of Finance 70, 1327-1363. 


\section{Figure 1: Parallel Trends in the Sensitivity of Excess Returns to Fund Flows}

Figure 1 plots the coefficient estimates of the performance-to-flow (i.e., smart-money) relationship after controlling for firm size, averaged across countries in the treatment and control samples. The treatment sample includes those firms that cross the filing threshold (and start filing 13F) during the sample period from 1999Q3 and 2016Q3. The control sample includes those firms that either never file, or always file, throughout our sample period. For each fund $i$ in the treatment group, we identify the first quarter $q$ that it becomes a $13 \mathrm{~F}$ filer. Next, we match fund $i$ with all funds in the control group at quarter $q$. We then consider the observations for fund $i$ and its control group at quarters $q-1, q-2$, and $q-3$. We then estimate the following cross-sectional regression for the treatment and control group, for each of the three quarters leading up to the filing event: ExcessRet $_{i, q+1}=\alpha+\beta_{1}$ Flow $_{i, q}+\beta_{2} \operatorname{LogSize}_{i, q-1}+\varepsilon_{i, q}$. The values of $\beta_{1}$ are then plotted below.

\section{Sensitivity of Past Flows to Future Performance}

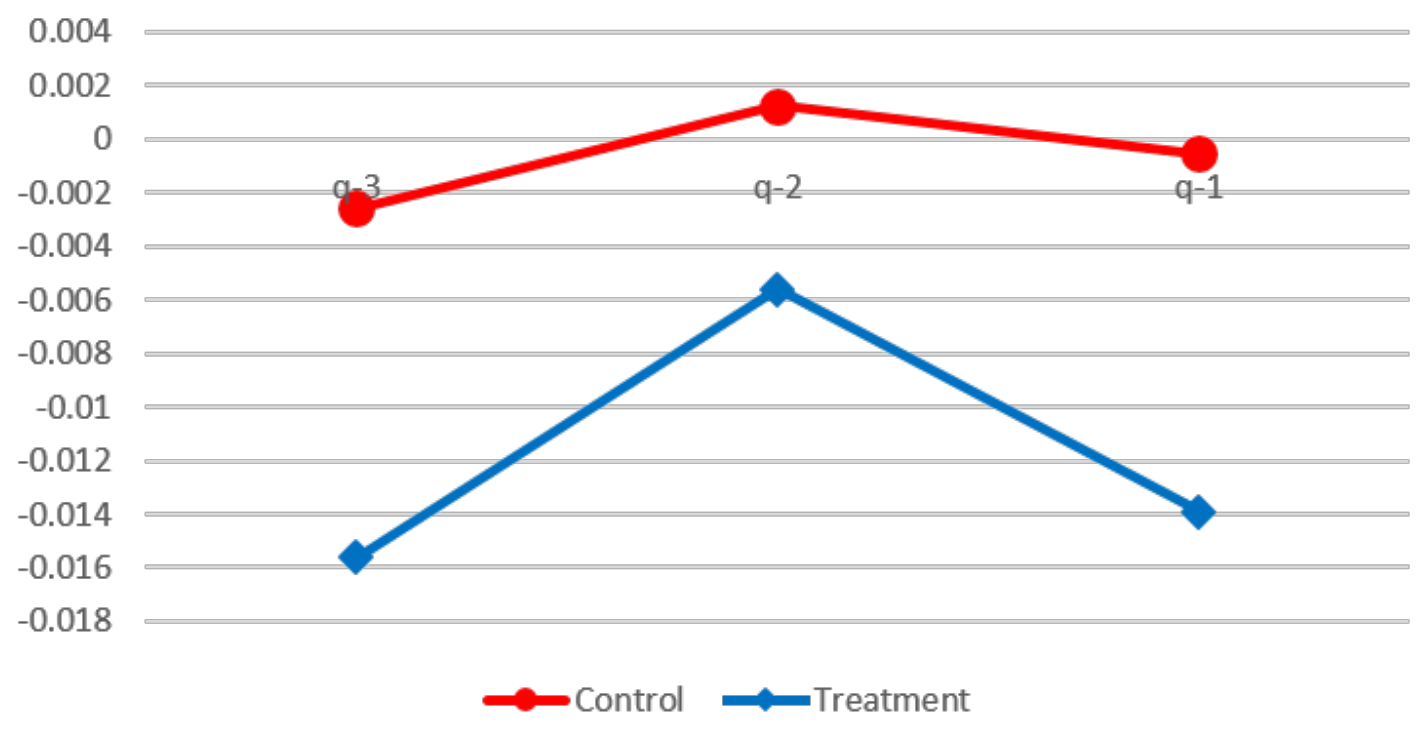


Table 1: Summary Statistics

This table presents the summary statistics of our sample of hedge funds between 1999Q3 and 2016Q3. Following Shi (2017), we exclude fund of hedge funds in our sample. Flow is the percentage fund flow during each calendar quarter. Excess Return are quarterly compounded excess return over the risk-free rate. $\mathrm{FH}^{7}$ Alpha is the quarterly compounded Fung and Hsieh (2001) seven-factor alpha, FH8 Alpha is the quarterly compounded Fung and Hsieh (2001) plus momentum eight-factor alpha; both alpha measures are calculated following Agarwal et al. (2018b). Fund Size is the fund's assets under management at each quarter end. Fund Age is the number of months since fund inception. Return Volatility is the return volatility using fund returns during between month $t-11$ and $t$.

\begin{tabular}{lcccccc}
\hline Variable & N & Mean & StdDev & Q1 & Median & Q3 \\
\hline Flow (\%/qtr) & 52897 & -0.270 & 18.350 & -5.315 & -0.179 & 3.375 \\
Excess Return (\%/qtr) & 52897 & 1.323 & 9.326 & -2.182 & 1.107 & 4.653 \\
FH7 Alpha (\%/qtr) & 52897 & 0.766 & 9.417 & -2.869 & 0.522 & 3.869 \\
FH8 Alpha (\%/qtr) & 52897 & 0.745 & 9.476 & -2.961 & 0.496 & 3.960 \\
Fund Size (millions \$) & 52897 & 218.450 & 825.143 & 16.830 & 54.057 & 177.760 \\
Fund Age (months) & 52897 & 103.797 & 54.760 & 62.000 & 89.000 & 131.000 \\
Return Volatility (\%) & 52897 & 11.263 & 9.917 & 4.678 & 8.520 & 14.699 \\
\hline \hline
\end{tabular}


Table 2: Portfolio Sorts

This table presents the portfolio sorting results. We perform the following $(2 \times 4)$ portfolio sorting analysis: at the end of every calendar quarter $q$, we first sort hedge funds into two groups: 13F-filers, and non-13F filers. Within each group, we sort funds based on fund flows during quarter $q$ into four quartiles (labelled Low, Q2, Q3, and High). Within each group-quartile, we form value-weighted portfolios, and rebalance quarterly. The following table reports the monthly excess returns (Panel A), FH7 alpha (Panel B), and FH8 alpha (Panel C). The first four columns report the portfolios sorted by flows, and the fifth column reports the long-short portfolio constructed as the highflow portfolio minus the low-flow portfolio. This high-minus-low portfolio is our measure of smart money. The first row reports the non-filer groups, the second row reports the filer groups, and the third row reports the long-short portfolio constructed as the filer group minus the non-filer group. The bottom right cell reports the difference in high-minus-low portfolios for the filers compared to non-filers. This measures how the smart money effect differs between the filer and non-filer groups.

\begin{tabular}{|c|c|c|c|c|c|}
\hline \multicolumn{6}{|c|}{ Panel A: Excess Return } \\
\hline & \multicolumn{4}{|c|}{ Flow } & \multirow[b]{2}{*}{ High-Low } \\
\hline & Low & Q2 & Q3 & High & \\
\hline NonFiler & $\begin{array}{c}0.404^{* * *} \\
(3.00)\end{array}$ & $\begin{array}{c}0.309^{*} \\
(1.92)\end{array}$ & $\begin{array}{c}0.308^{* *} \\
(2.02)\end{array}$ & $\begin{array}{c}0.332^{* *} \\
(2.46)\end{array}$ & $\begin{array}{l}-0.072 \\
(-0.91)\end{array}$ \\
\hline Filer & $\begin{array}{l}0.244 \\
(1.49)\end{array}$ & $\begin{array}{c}0.391^{* *} \\
(2.37)\end{array}$ & $\begin{array}{l}0.345 \\
(1.33)\end{array}$ & $\begin{array}{c}0.513^{* * *} \\
(3.92)\end{array}$ & $\begin{array}{c}0.269^{* *} \\
(2.15)\end{array}$ \\
\hline Filer-NonFiler & $\begin{array}{l}-0.160 \\
(-1.44)\end{array}$ & $\begin{array}{l}0.082 \\
(0.81)\end{array}$ & $\begin{array}{l}0.037 \\
(0.23)\end{array}$ & $\begin{array}{c}0.181^{* *} \\
(2.05)\end{array}$ & $\begin{array}{c}0.341^{* * *} \\
(2.60)\end{array}$ \\
\hline \multicolumn{6}{|c|}{ Panel B: Fung-Hsieh 7-factor Alpha } \\
\hline & \multicolumn{4}{|c|}{ Flow } & \\
\hline & Low & Q2 & Q3 & High & High-Low \\
\hline NonFiler & $\begin{array}{c}0.226^{* *} \\
(2.41)\end{array}$ & $\begin{array}{l}0.092 \\
(0.92)\end{array}$ & $\begin{array}{l}0.105 \\
(0.98)\end{array}$ & $\begin{array}{l}0.140 \\
(1.54)\end{array}$ & $\begin{array}{l}-0.085 \\
(-1.06)\end{array}$ \\
\hline Filer & $\begin{array}{l}0.062 \\
(0.64)\end{array}$ & $\begin{array}{l}0.177 \\
(1.62)\end{array}$ & $\begin{array}{l}0.109 \\
(0.54)\end{array}$ & $\begin{array}{c}0.282^{* * *} \\
(2.75)\end{array}$ & $\begin{array}{c}0.220^{*} \\
(1.82)\end{array}$ \\
\hline Filer-NonFiler & $\begin{array}{l}-0.164 \\
(-1.58)\end{array}$ & $\begin{array}{l}0.086 \\
(0.77)\end{array}$ & $\begin{array}{l}0.004 \\
(0.03)\end{array}$ & $\begin{array}{l}0.141 \\
(1.37)\end{array}$ & $\begin{array}{c}0.305^{* *} \\
(2.39)\end{array}$ \\
\hline \multicolumn{6}{|c|}{ Panel C: Fung-Hsieh 8-factor Alpha } \\
\hline & \multicolumn{4}{|c|}{ Flow } & \\
\hline & Low & Q2 & Q3 & High & High-Low \\
\hline NonFiler & $\begin{array}{c}0.205^{* *} \\
(2.28)\end{array}$ & $\begin{array}{l}0.071 \\
(0.75)\end{array}$ & $\begin{array}{l}0.078 \\
(0.83)\end{array}$ & $\begin{array}{l}0.111 \\
(1.36)\end{array}$ & $\begin{array}{l}-0.094 \\
(-1.18)\end{array}$ \\
\hline Filer & $\begin{array}{l}0.057 \\
(0.58)\end{array}$ & $\begin{array}{l}0.146 \\
(1.54)\end{array}$ & $\begin{array}{l}0.079 \\
(0.43)\end{array}$ & $\begin{array}{c}0.249^{* *} \\
(2.58)\end{array}$ & $\begin{array}{l}0.192 \\
(1.64)\end{array}$ \\
\hline Filer-NonFiler & $\begin{array}{l}-0.147 \\
(-1.45)\end{array}$ & $\begin{array}{l}0.075 \\
(0.68)\end{array}$ & $\begin{array}{l}0.001 \\
(0.01)\end{array}$ & $\begin{array}{l}0.138 \\
(1.35)\end{array}$ & $\begin{array}{c}0.286^{* *} \\
(2.25)\end{array}$ \\
\hline
\end{tabular}


Table 3: Baseline Smart Money Analysis

This table presents the baseline smart money analysis. We estimate the following regression specification: Performance $e_{i, q+1}=\alpha_{i}+\alpha_{q}+\beta_{1}$ Flow $_{i, q} \times 13 F_{i} \times$ Post $_{i, q}+\beta_{2} 13 F_{i} \times$ Post $_{i, q}+\beta_{4}$ Flow $_{i, q} \times$ $13 F_{i}+\beta_{5}$ Flow $_{i, q}+\gamma$ Controls $_{i, q}+\varepsilon_{i, q}$. Performance $i, q+1$ is the return on fund $i$ in quarter $q+1$. Depending on the specification, performance is measured as excess returns, FH7 alpha, and FH8 alpha. Flow $i, q$ is the percentage fund flow of fund $i$ in quarter $q .13 F_{i}$ is an indicator for whether fund $i$ ever files Form 13F. It captures the treatment effect. Post $t_{i, q}$ is an indicator for whether fund $i$ has ever filed Form 13F as of quarter $q$. Controls $s_{i, q}$ is a vector of fund level controls, including the logarithm of assets under management, the logarithm of fund age in months, average fund flows in quarter $q-1, q-2$, and $q-3$, average returns in quarter $q, q-1, q-2$, and $q-3$, and the volatility of past 12 month returns. $\alpha_{i}$ and $\alpha_{q}$ are fund- and quarter-level fixed effects, respectively. We cluster standard errors at the management company level.

\begin{tabular}{|c|c|c|c|c|c|c|c|c|c|}
\hline & $\begin{array}{c}(1) \\
\text { Excess }\end{array}$ & $\begin{array}{c}(2) \\
\text { Excess }\end{array}$ & $\begin{array}{c}(3) \\
\text { Excess }\end{array}$ & $\begin{array}{l}(4) \\
\text { FH7 }\end{array}$ & $\begin{array}{l}(5) \\
\text { FH7 }\end{array}$ & $\begin{array}{l}(6) \\
\text { FH7 }\end{array}$ & $\begin{array}{l}(7) \\
\text { FH8 }\end{array}$ & $\begin{array}{l}(8) \\
\text { FH8 }\end{array}$ & $\begin{array}{l}(9) \\
\text { FH8 }\end{array}$ \\
\hline Flow $\times 13 \mathrm{~F} \times$ Post & $\begin{array}{c}0.025^{* * *} \\
(3.24)\end{array}$ & $\begin{array}{c}0.023^{* * *} \\
(2.87)\end{array}$ & $\begin{array}{c}0.024^{* * *} \\
(3.18)\end{array}$ & $\begin{array}{c}0.019^{* *} \\
(2.28)\end{array}$ & $\begin{array}{c}0.016^{* *} \\
(2.01)\end{array}$ & $\begin{array}{c}0.019^{* *} \\
(2.31)\end{array}$ & $\begin{array}{c}0.024^{* * *} \\
(2.93)\end{array}$ & $\begin{array}{c}0.021^{* * *} \\
(2.67)\end{array}$ & $\begin{array}{c}0.023^{* * *} \\
(2.90)\end{array}$ \\
\hline $13 \mathrm{~F} \times$ Post & $\begin{array}{l}-0.302 \\
(-1.15)\end{array}$ & $\begin{array}{c}-0.506^{* *} \\
(-2.04)\end{array}$ & $\begin{array}{l}-0.293 \\
(-1.06)\end{array}$ & $\begin{array}{l}0.139 \\
(0.45)\end{array}$ & $\begin{array}{l}-0.023 \\
(-0.08)\end{array}$ & $\begin{array}{l}0.201 \\
(0.65)\end{array}$ & $\begin{array}{l}0.058 \\
(0.18)\end{array}$ & $\begin{array}{l}-0.097 \\
(-0.30)\end{array}$ & $\begin{array}{l}0.095 \\
(0.28)\end{array}$ \\
\hline Flow $\times 13 \mathrm{~F}$ & $\begin{array}{c}-0.020^{* * * *} \\
(-2.69)\end{array}$ & $\begin{array}{c}-0.019^{* *} \\
(-2.52)\end{array}$ & $\begin{array}{c}-0.020^{* * *} \\
(-2.59)\end{array}$ & $\begin{array}{l}-0.012 \\
(-1.45)\end{array}$ & $\begin{array}{l}-0.010 \\
(-1.32)\end{array}$ & $\begin{array}{l}-0.012 \\
(-1.46)\end{array}$ & $\begin{array}{c}-0.016^{* *} \\
(-2.10)\end{array}$ & $\begin{array}{c}-0.015^{* *} \\
(-1.99)\end{array}$ & $\begin{array}{c}-0.016^{* *} \\
(-2.06)\end{array}$ \\
\hline Flow & $\begin{array}{c}-0.015^{* * * *} \\
(-4.88)\end{array}$ & $\begin{array}{c}-0.007^{* *} \\
(-2.26)\end{array}$ & $\begin{array}{c}-0.013^{* * *} \\
(-4.27)\end{array}$ & $\begin{array}{c}-0.014^{* * *} \\
(-4.63)\end{array}$ & $\begin{array}{c}-0.008^{* * *} \\
(-2.70)\end{array}$ & $\begin{array}{c}-0.015^{* * *} \\
(-4.67)\end{array}$ & $\begin{array}{c}-0.014^{* * *} \\
(-4.42)\end{array}$ & $\begin{array}{c}-0.007^{* *} \\
(-2.45)\end{array}$ & $\begin{array}{c}-0.013^{* * *} \\
(-4.15)\end{array}$ \\
\hline LogSize & $\begin{array}{c}-1.518^{* * * *} \\
(-15.20)\end{array}$ & & $\begin{array}{c}-1.545^{* * *} \\
(-14.62)\end{array}$ & $\begin{array}{c}-1.136^{* * *} \\
(-10.46)\end{array}$ & & $\begin{array}{c}-1.142^{* * *} \\
(-10.17)\end{array}$ & $\begin{array}{c}-1.148^{* * *} \\
(-10.23)\end{array}$ & & $\begin{array}{c}-1.163^{* * *} \\
(-9.89)\end{array}$ \\
\hline Size(millions \$) & & $\begin{array}{c}-0.001^{* * * *} \\
(-4.40)\end{array}$ & & & $\begin{array}{c}-0.001^{* * *} \\
(-3.70)\end{array}$ & & & $\begin{array}{c}-0.001^{* * *} \\
(-3.82)\end{array}$ & \\
\hline $\mathrm{Size}^{2}$ & & $\begin{array}{c}0.000^{* * *} \\
(4.47)\end{array}$ & & & $\begin{array}{c}0.000^{* * *} \\
(3.91)\end{array}$ & & & $\begin{array}{c}0.000^{* * *} \\
(4.00)\end{array}$ & \\
\hline LogAge & & & $\begin{array}{c}-1.685^{* * *} \\
(-3.76)\end{array}$ & & & $\begin{array}{c}-2.077^{* * *} \\
(-4.00)\end{array}$ & & & $\begin{array}{c}-2.080^{* * *} \\
(-4.09)\end{array}$ \\
\hline LagFlow & & & $\begin{array}{c}0.012^{* * *} \\
(3.67)\end{array}$ & & & $\begin{array}{l}0.002 \\
(0.58)\end{array}$ & & & $\begin{array}{l}0.003 \\
(0.91)\end{array}$ \\
\hline LagRet & & & $\begin{array}{c}-0.113^{* * *} \\
(-8.17)\end{array}$ & & & $\begin{array}{l}-0.024 \\
(-1.04)\end{array}$ & & & $\begin{array}{c}-0.066^{* * *} \\
(-3.17)\end{array}$ \\
\hline Volatility & & & $\begin{array}{c}0.104^{* * *} \\
(7.86)\end{array}$ & & & $\begin{array}{l}0.011 \\
(0.59)\end{array}$ & & & $\begin{array}{l}0.011 \\
(0.62)\end{array}$ \\
\hline Time FE & Yes & Yes & Yes & Yes & Yes & Yes & Yes & Yes & Yes \\
\hline Fund FE & Yes & Yes & Yes & Yes & Yes & Yes & Yes & Yes & Yes \\
\hline Observations & 52897 & 52897 & 52897 & 52897 & 52897 & 52897 & 52897 & 52897 & 52897 \\
\hline Adjusted $R^{2}$ & 0.196 & 0.185 & 0.202 & 0.101 & 0.095 & 0.102 & 0.090 & 0.083 & 0.091 \\
\hline \# of Clusters & 1775 & 1775 & 1775 & 1775 & 1775 & 1775 & 1775 & 1775 & 1775 \\
\hline Clustered by & Company & Company & Company & Company & Company & Company & Company & Company & Company \\
\hline
\end{tabular}

${ }^{*} p<0.1,{ }^{* *} p<0.05,{ }^{* * *} p<0.01$ 
Table 4: RDD Smart Money Analysis

This table reports the regression results in the spirit of a regression discontinuity design. We conduct two subsample analyses: (i) for funds that experience a filing status switch (i.e., from nonfiling to filing), we restrict the sample to those fund-quarter observations from the four-year window around the filing status change; and (ii) following Shi (2017), we restrict the sample to fund-quarter observations where the parent company AUM is between $\$ 50$ million and $\$ 300$ million. We estimate the following regression specification: Performance for $_{i+1}=\alpha_{i}+\alpha_{q}+\beta_{1}$ Flow $_{i, q} \times 13 F_{i} \times$ Post $_{i, q}+$ $\beta_{2} 13 F_{i} \times$ Post $_{i, q}+\beta_{4}$ Flow $_{i, q} \times 13 F_{i}+\beta_{5}$ Flow $_{i, q}+\gamma$ Controls $_{i, q}+\varepsilon_{i, q}$. Performance Pef $_{i, q}$ is the return on fund $i$ in quarter $q+1$. Depending on the specification, performance is measured as excess returns, FH7 alpha, and FH8 alpha. $F l_{\text {ow }}$ is the percentage fund flow of fund $i$ in quarter q. $13 F_{i}$ is an indicator for whether fund $i$ ever files Form 13F. It captures the treatment effect. Post $_{i, q}$ is an indicator for whether fund $i$ has ever filed Form $13 \mathrm{~F}$ as of quarter q. Controls $s_{i, q}$ is a vector of fund level controls, including the logarithm of assets under management, the logarithm of fund age in months, average fund flows in quarter $q-1, q-2$, and $q-3$, average returns in quarter $q, q-1, q-2$, and $q-3$, and the volatility of past 12 month returns. $\alpha_{i}$ and $\alpha_{q}$ are fund- and quarter-level fixed effects, respectively. We cluster standard errors at the management company level. Columns 1, 2, and 3 report the results using subsample (i), and columns 4, 5, and 6 report the results using subsample (ii).

\begin{tabular}{|c|c|c|c|c|c|c|}
\hline & \multicolumn{3}{|c|}{ Panel A: Subsample (i) } & \multicolumn{3}{|c|}{ Panel B: Subsample (ii) } \\
\hline & $(1)$ & $(2)$ & $(3)$ & (4) & $(5)$ & $(6)$ \\
\hline & Excess & FH7 & FH8 & Excess & FH7 & FH8 \\
\hline Flow $\times 13 \mathrm{~F} \times$ Post & $\begin{array}{c}0.037^{* * *} \\
(3.28)\end{array}$ & $\begin{array}{c}0.026^{* *} \\
(2.21)\end{array}$ & $\begin{array}{c}0.026^{* *} \\
(2.27)\end{array}$ & $\begin{array}{c}0.032^{* * *} \\
(3.24)\end{array}$ & $\begin{array}{c}0.042^{* * *} \\
(3.55)\end{array}$ & $\begin{array}{c}0.048^{* * *} \\
(4.01)\end{array}$ \\
\hline $13 \mathrm{~F} \times$ Post & $\begin{array}{c}-0.878^{*} \\
(-1.66)\end{array}$ & $\begin{array}{l}-0.545 \\
(-0.92)\end{array}$ & $\begin{array}{l}-0.377 \\
(-0.61)\end{array}$ & $\begin{array}{l}0.118 \\
(0.24)\end{array}$ & $\begin{array}{l}0.559 \\
(1.05)\end{array}$ & $\begin{array}{l}0.349 \\
(0.59)\end{array}$ \\
\hline Flow $\times 13 \mathrm{~F}$ & & & & $\begin{array}{c}-0.029^{* * *} \\
(-2.82)\end{array}$ & $\begin{array}{c}-0.033^{* * *} \\
(-2.86)\end{array}$ & $\begin{array}{c}-0.036^{* * *} \\
(-3.11)\end{array}$ \\
\hline Flow & $\begin{array}{c}-0.041^{* * *} \\
(-4.90)\end{array}$ & $\begin{array}{c}-0.027^{* * *} \\
(-3.00)\end{array}$ & $\begin{array}{c}-0.028^{* * *} \\
(-3.43)\end{array}$ & $\begin{array}{c}-0.014^{* *} \\
(-2.41)\end{array}$ & $\begin{array}{c}-0.012^{*} \\
(-1.95)\end{array}$ & $\begin{array}{c}-0.013^{* *} \\
(-2.16)\end{array}$ \\
\hline LogSize & $\begin{array}{c}-2.056^{* * *} \\
(-6.03)\end{array}$ & $\begin{array}{c}-1.602^{* * *} \\
(-4.56)\end{array}$ & $\begin{array}{c}-1.694^{* * *} \\
(-4.33)\end{array}$ & $\begin{array}{c}-2.132^{* * *} \\
(-9.56)\end{array}$ & $\begin{array}{c}-1.730^{* * *} \\
(-6.77)\end{array}$ & $\begin{array}{c}-1.677^{* * *} \\
(-6.12)\end{array}$ \\
\hline LogAge & $\begin{array}{l}-1.466 \\
(-0.70)\end{array}$ & $\begin{array}{l}-3.066 \\
(-1.44)\end{array}$ & $\begin{array}{l}-3.115 \\
(-1.37)\end{array}$ & $\begin{array}{l}-0.853 \\
(-1.01)\end{array}$ & $\begin{array}{l}-1.421 \\
(-1.25)\end{array}$ & $\begin{array}{l}-1.971^{*} \\
(-1.72)\end{array}$ \\
\hline LagFlow & $\begin{array}{l}0.012 \\
(1.30)\end{array}$ & $\begin{array}{l}-0.010 \\
(-1.08)\end{array}$ & $\begin{array}{l}-0.013 \\
(-1.32)\end{array}$ & $\begin{array}{c}0.015^{* * *} \\
(2.81)\end{array}$ & $\begin{array}{c}0.010^{*} \\
(1.80)\end{array}$ & $\begin{array}{c}0.012^{* *} \\
(2.00)\end{array}$ \\
\hline LagRet & $\begin{array}{c}-0.236^{* * *} \\
(-4.29)\end{array}$ & $\begin{array}{c}-0.186^{* * *} \\
(-2.72)\end{array}$ & $\begin{array}{c}-0.196^{* *} \\
(-2.39)\end{array}$ & $\begin{array}{c}-0.113^{* * *} \\
(-4.89)\end{array}$ & $\begin{array}{l}-0.038 \\
(-0.80)\end{array}$ & $\begin{array}{c}-0.088^{* *} \\
(-2.09)\end{array}$ \\
\hline Volatility & $\begin{array}{c}0.196^{* * *} \\
(3.41)\end{array}$ & $\begin{array}{c}0.124^{*} \\
(1.92)\end{array}$ & $\begin{array}{c}0.129^{*} \\
(1.82)\end{array}$ & $\begin{array}{c}0.114^{* * *} \\
(3.87)\end{array}$ & $\begin{array}{l}0.008 \\
(0.25)\end{array}$ & $\begin{array}{l}0.035 \\
(1.10)\end{array}$ \\
\hline Time FE & Yes & Yes & Yes & Yes & Yes & Yes \\
\hline Fund FE & Yes & Yes & Yes & Yes & Yes & Yes \\
\hline Observations & 5638 & 5638 & 5638 & 19119 & 19119 & 19119 \\
\hline Adjusted $R^{2}$ & 0.270 & 0.144 & 0.125 & 0.223 & 0.122 & 0.121 \\
\hline
\end{tabular}

${ }^{*} p<0.1,{ }^{* *} p<0.05,{ }^{* * *} p<0.01$ 
Table 5: Placebo Smart Money Analysis

This table repeats the analysis of Table 3 but with a placebo subsample. We limit the analysis to only fund-of-hedge funds ("FoFs"). FoFs do not hold 13(f) securities, thus Form 13F should be less informative for FoFs. We estimate the following regression specification: Performance ${ }_{i, q+1}=$ $\alpha_{i}+\alpha_{q}+\beta_{1}$ Flow $_{i, q} \times 13 F_{i} \times$ Post $_{i, q}+\beta_{2} 13 F_{i} \times$ Post $_{i, q}+\beta_{4}$ Flow $_{i, q} \times 13 F_{i}+\beta_{5}$ Flow $_{i, q}+\gamma$ Controls $_{i, q}+$ $\varepsilon_{i, q}$. Performance $i, q+1$ is the return on fund $i$ in quarter $q+1$. Depending on the specification, performance is measured as excess returns, FH7 alpha, and FH8 alpha. Flow $w_{i, q}$ is the percentage fund flow of fund $i$ in quarter $q .13 F_{i}$ is an indicator for whether fund $i$ ever files Form 13F. It captures the treatment effect. Post $t_{i, q}$ is an indicator for whether fund $i$ has ever filed Form $13 \mathrm{~F}$ as of quarter $q$. Control $s_{i, q}$ is a vector of fund level controls, including the logarithm of assets under management, the logarithm of fund age in months, average fund flows in quarter $q-1, q-2$, and $q-3$, average returns in quarter $q, q-1, q-2$, and $q-3$, and the volatility of past 12 month returns. $\alpha_{i}$ and $\alpha_{q}$ are fund- and quarter-level fixed effects, respectively. We cluster standard errors at the management company level.

\begin{tabular}{|c|c|c|c|c|c|c|c|c|c|}
\hline & (1) & $(2)$ & (3) & $(4)$ & (5) & (6) & (7) & $(8)$ & (9) \\
\hline & Excess & Excess & Excess & FH7 & FH7 & FH7 & FH8 & FH8 & FH8 \\
\hline \multirow[t]{2}{*}{ Flow $\times 13 \mathrm{~F} \times$ Post } & -0.004 & -0.005 & -0.005 & 0.004 & 0.004 & 0.005 & 0.007 & 0.007 & 0.008 \\
\hline & $(-0.53)$ & $(-0.66)$ & $(-0.59)$ & $(0.40)$ & $(0.38)$ & $(0.48)$ & $(0.77)$ & $(0.75)$ & $(0.82)$ \\
\hline \multirow[t]{2}{*}{$13 \mathrm{~F} \times$ Post } & -0.353 & -0.366 & -0.363 & 0.047 & 0.017 & 0.097 & -0.001 & -0.037 & 0.048 \\
\hline & $(-1.48)$ & $(-1.63)$ & $(-1.33)$ & $(0.13)$ & $(0.05)$ & $(0.26)$ & $(-0.00)$ & $(-0.10)$ & $(0.12)$ \\
\hline \multirow[t]{2}{*}{ Flow $\times 13 \mathrm{~F}$} & -0.005 & -0.004 & -0.004 & -0.002 & -0.002 & -0.003 & -0.005 & -0.005 & -0.005 \\
\hline & $(-0.83)$ & $(-0.73)$ & $(-0.77)$ & $(-0.35)$ & $(-0.32)$ & $(-0.40)$ & $(-0.72)$ & $(-0.70)$ & $(-0.72)$ \\
\hline \multirow[t]{2}{*}{ Flow } & $-0.004^{* * *}$ & -0.002 & $-0.003^{* *}$ & -0.001 & 0.001 & -0.002 & -0.001 & 0.001 & -0.001 \\
\hline & $(-3.48)$ & $(-1.61)$ & $(-2.58)$ & $(-0.85)$ & $(0.64)$ & $(-1.40)$ & $(-0.79)$ & $(0.75)$ & $(-1.17)$ \\
\hline \multirow[t]{2}{*}{ LogSize } & $-0.648^{* * *}$ & & $-0.688^{* * *}$ & $-0.479^{* * *}$ & & $-0.522^{* * *}$ & $-0.521^{* * *}$ & & $-0.595^{* * *}$ \\
\hline & $(-7.64)$ & & $(-7.40)$ & $(-4.96)$ & & $(-5.42)$ & $(-5.53)$ & & $(-6.21)$ \\
\hline \multirow[t]{2}{*}{ Size(millions \$) } & & $-0.001 * * *$ & & & $-0.001^{* * *}$ & & & $-0.001^{* * *}$ & \\
\hline & & $(-6.58)$ & & & $(-4.16)$ & & & $(-4.45)$ & \\
\hline \multirow[t]{2}{*}{$\operatorname{Size}^{2}$} & & $0.000^{* * *}$ & & & $0.000^{* * *}$ & & & $0.000^{* * *}$ & \\
\hline & & $(6.09)$ & & & $(3.52)$ & & & $(3.76)$ & \\
\hline \multirow[t]{2}{*}{ LogAge } & & & -0.365 & & & -0.409 & & & -0.550 \\
\hline & & & $(-1.12)$ & & & $(-1.12)$ & & & $(-1.55)$ \\
\hline \multirow[t]{2}{*}{ LagFlow } & & & $0.004^{*}$ & & & 0.001 & & & 0.003 \\
\hline & & & $(1.95)$ & & & $(0.38)$ & & & $(1.34)$ \\
\hline \multirow[t]{2}{*}{ LagRet } & & & $-0.131^{* * *}$ & & & 0.018 & & & -0.053 \\
\hline & & & $(-3.48)$ & & & $(0.42)$ & & & $(-1.18)$ \\
\hline \multirow[t]{2}{*}{ Volatility } & & & 0.016 & & & $-0.100 * *$ & & & $-0.123^{* * *}$ \\
\hline & & & $(0.59)$ & & & $(-2.36)$ & & & $(-3.04)$ \\
\hline Time FE & Yes & Yes & Yes & Yes & Yes & Yes & Yes & Yes & Yes \\
\hline Fund FE & Yes & Yes & Yes & Yes & Yes & Yes & Yes & Yes & Yes \\
\hline Observations & 20330 & 20330 & 20330 & 20330 & 20330 & 20330 & 20330 & 20330 & 20330 \\
\hline Adjusted $R^{2}$ & 0.392 & 0.388 & 0.395 & 0.306 & 0.304 & 0.309 & 0.245 & 0.243 & 0.251 \\
\hline
\end{tabular}

${ }^{*} p<0.1,{ }^{* *} p<0.05,{ }^{* * *} p<0.01$ 
Table 6: Persistence of Smart Money Effect

This table studies the smart money effect at longer horizons, going out two-, three-, and fourquarters into the future. We estimate the following regression specification: Performance ${ }_{i, q+t}=$ $\alpha_{i}+\alpha_{q}+\beta_{1}$ Flow $_{i, q} \times 13 F_{i} \times$ Post $_{i, q}+\beta_{2} 13 F_{i} \times$ Post $_{i, q}+\beta_{4}$ Flow $_{i, q} \times 13 F_{i}+\beta_{5}$ Flow $_{i, q}+\gamma$ Controls $_{i, q}+$ $\varepsilon_{i, q}$. Performance $e_{i, q+t}$ is the return on fund $i$ in quarter $q+t$. Depending on the specification, performance is measured as excess returns, FH7 alpha, and FH8 alpha. Flow $w_{i, q}$ is the percentage fund flow of fund $i$ in quarter $q .13 F_{i}$ is an indicator for whether fund $i$ ever files Form 13F. It captures the treatment effect. Post $t_{i, q}$ is an indicator for whether fund $i$ has ever filed Form 13F as of quarter $q$. Controls $s_{i, q}$ is a vector of fund level controls, including the logarithm of assets under management, the logarithm of fund age in months, average fund flows in quarter $q-1, q-2$, and $q-3$, average returns in quarter $q, q-1, q-2$, and $q-3$, and the volatility of past 12 month returns. $\alpha_{i}$ and $\alpha_{q}$ are fund- and quarter-level fixed effects, respectively. We cluster standard errors at the management company level.

\begin{tabular}{|c|c|c|c|c|c|c|c|c|c|}
\hline & $(1)$ & $(2)$ & (3) & $(4)$ & $(5)$ & $(6)$ & $(7)$ & $(8)$ & (9) \\
\hline & $\mathrm{Q}+2$ & $\mathrm{Q}+3$ & $\mathrm{Q}+4$ & $\mathrm{Q}+2$ & $\mathrm{Q}+3$ & $\mathrm{Q}+4$ & $\mathrm{Q}+2$ & $\mathrm{Q}+3$ & $\mathrm{Q}+4$ \\
\hline & Excess & Excess & Excess & FH7 & FH7 & FH7 & FH8 & $\mathrm{FH} 8$ & FH8 \\
\hline \multirow[t]{2}{*}{ Flow $\times 13 \mathrm{~F} \times$ Post } & 0.002 & 0.009 & -0.010 & $0.013^{* *}$ & -0.003 & -0.000 & $0.013^{*}$ & 0.000 & -0.001 \\
\hline & $(0.22)$ & (1.38) & $(-1.46)$ & $(1.97)$ & $(-0.42)$ & $(-0.02)$ & $(1.81)$ & $(0.02)$ & $(-0.09)$ \\
\hline \multirow[t]{2}{*}{$13 \mathrm{~F} \times$ Post } & -0.239 & -0.116 & -0.073 & 0.268 & $0.619^{* *}$ & $0.635^{* *}$ & 0.311 & $0.607^{*}$ & $0.610^{*}$ \\
\hline & $(-0.85)$ & $(-0.45)$ & $(-0.29)$ & $(0.90)$ & $(2.07)$ & $(2.11)$ & $(0.96)$ & $(1.90)$ & $(1.90)$ \\
\hline \multirow[t]{2}{*}{ Flow $\times 13 \mathrm{~F}$} & 0.002 & -0.004 & -0.003 & $-0.012^{*}$ & 0.004 & -0.006 & -0.010 & 0.003 & -0.006 \\
\hline & $(0.25)$ & $(-0.70)$ & $(-0.44)$ & $(-1.69)$ & $(0.65)$ & $(-0.93)$ & $(-1.50)$ & $(0.49)$ & $(-0.83)$ \\
\hline \multirow[t]{2}{*}{ Flow } & $-0.009^{* * *}$ & $-0.012^{* * *}$ & -0.002 & $-0.015^{* * *}$ & $-0.014^{* * *}$ & -0.003 & $-0.016^{* * *}$ & $-0.013^{* * *}$ & -0.003 \\
\hline & $(-2.72)$ & $(-3.34)$ & $(-0.51)$ & $(-4.58)$ & $(-3.50)$ & $(-0.67)$ & $(-4.56)$ & $(-3.31)$ & $(-0.58)$ \\
\hline \multirow[t]{2}{*}{ LogSize } & $-1.373^{* * *}$ & $-1.271^{* * *}$ & $-1.052^{* * *}$ & $-1.107^{* * *}$ & $-1.046^{* * *}$ & $-0.953^{* * *}$ & $-1.094^{* * *}$ & $-0.994^{* * *}$ & $-0.908^{* * *}$ \\
\hline & $(-13.19)$ & $(-12.57)$ & $(-11.99)$ & $(-8.85)$ & $(-8.23)$ & $(-7.52)$ & $(-8.76)$ & $(-7.93)$ & $(-7.30)$ \\
\hline \multirow[t]{2}{*}{ LogAge } & $-1.230^{* *}$ & $-0.842^{*}$ & $-0.806^{*}$ & $-1.716^{* * *}$ & $-1.626^{* * *}$ & $-1.591^{* * *}$ & $-1.702^{* * *}$ & $-1.443^{* * *}$ & $-1.599^{* * *}$ \\
\hline & $(-2.57)$ & $(-1.82)$ & $(-1.70)$ & $(-3.24)$ & $(-2.99)$ & $(-2.83)$ & $(-3.26)$ & $(-2.73)$ & $(-2.92)$ \\
\hline \multirow[t]{2}{*}{ LagFlow } & $0.009^{* * *}$ & $0.009^{* * *}$ & 0.005 & 0.005 & $0.010^{* * *}$ & $0.008^{*}$ & $0.006^{*}$ & $0.008^{* *}$ & 0.005 \\
\hline & $(2.67)$ & $(2.72)$ & (1.64) & $(1.54)$ & $(2.63)$ & (1.95) & (1.74) & $(2.00)$ & $(1.09)$ \\
\hline \multirow[t]{2}{*}{ LagRet } & $-0.234^{* * *}$ & $-0.158^{* * *}$ & $-0.202^{* * *}$ & $-0.053^{* * *}$ & $-0.078^{* * *}$ & $-0.074^{* * *}$ & $-0.056^{* * *}$ & $-0.068^{* * *}$ & $-0.067^{* *}$ \\
\hline & $(-18.04)$ & $(-11.87)$ & $(-11.68)$ & $(-2.74)$ & $(-4.21)$ & $(-3.02)$ & $(-2.82)$ & $(-3.00)$ & $(-2.25)$ \\
\hline \multirow[t]{2}{*}{ Volatility } & $0.086^{* * *}$ & $0.058^{* * *}$ & $0.074^{* * *}$ & -0.009 & 0.014 & $0.034^{* *}$ & 0.010 & 0.024 & $0.038^{* * *}$ \\
\hline & $(7.16)$ & $(5.39)$ & $(7.28)$ & $(-0.55)$ & $(0.72)$ & $(2.42)$ & $(0.66)$ & $(1.59)$ & $(2.76)$ \\
\hline Time FE & Yes & Yes & Yes & Yes & Yes & Yes & Yes & Yes & Yes \\
\hline Fund FE & Yes & Yes & Yes & Yes & Yes & Yes & Yes & Yes & Yes \\
\hline Observations & 50601 & 48377 & 46206 & 50601 & 48357 & 46170 & 50601 & 48357 & 46170 \\
\hline Adjusted $R^{2}$ & 0.207 & 0.204 & 0.208 & 0.097 & 0.099 & 0.099 & 0.087 & 0.088 & 0.086 \\
\hline
\end{tabular}

${ }^{*} p<0.1,{ }^{* *} p<0.05,{ }^{* * *} p<0.01$ 


\section{Table 7: Robustness of Smart Money Effect (1)}

This table reports the robustness test using alternative measures and alternative samples. The baseline model is specified as follows: Performance ${ }_{i, q+1}=\alpha_{i}+\alpha_{q}+\beta_{1}$ Flow $_{i, q} \times 13 F_{i} \times$ Post $_{i, q}+$ $\beta_{2} 13 F_{i} \times$ Post $_{i, q}+\beta_{4}$ Flow $_{i, q} \times 13 F_{i}+\beta_{5}$ Flow $_{i, q}+\gamma$ Controls $_{i, q}+\varepsilon_{i, q}$. Performance $_{i, q+1}$ is the return on fund $i$ in quarter $q+1$. Depending on the specification, performance is measured as excess returns, FH7 alpha, and FH8 alpha. Flow $w_{i, q}$ is the percentage fund flow of fund $i$ in quarter q. $13 F_{i}$ is an indicator for whether fund $i$ ever files Form 13F. It captures the treatment effect. Post $_{i, q}$ is an indicator for whether fund $i$ has ever filed Form $13 \mathrm{~F}$ as of quarter $q$. Controls $s_{i, q}$ is a vector of fund level controls, including the logarithm of assets under management, the logarithm of fund age in months, average fund flows in quarter $q-1, q-2$, and $q-3$, average returns in quarter $q, q-1, q-2$, and $q-3$, and the volatility of past 12 month returns. $\alpha_{i}$ and $\alpha_{q}$ are fund- and quarter-level fixed effects, respectively. We cluster standard errors at the management company level. In Columns 1, 2, and 3, we re-estimate our baseline regression model using alternative alphas: CAPM, Fama-French 3-factor, and Carhart 4-factor alphas (same method as we calculate the 7factor and 8-factor alphas). In Columns 4, 5, and 6, we re-estimate our baseline regression model after including all the dropped observations (i.e., the fund-quarter observations around filing status switch and after the very last $13 \mathrm{~F}$ filings). In Columns 7, 8 , and 9 , we re-estimate our baseline regression model using only fund-quarters observations from funds that have ever changed filing status (i.e., from non-filing to filing); we further restrict the sample so that a given fund has at least one observation before- and one observation after- the status change. In Columns 10, 11, and 12 , we re-estimate our baseline regression model using only funds that never filed $13 \mathrm{~F}$ as control group.

\begin{tabular}{|c|c|c|c|c|c|c|c|c|c|c|c|c|}
\hline & \multicolumn{3}{|c|}{ Panel A: Alt. Perf. } & \multicolumn{3}{|c|}{ Panel B: Full Sample } & \multicolumn{3}{|c|}{ Panel C: Switcher Sample } & \multicolumn{3}{|c|}{ Panel D: No Always-filers } \\
\hline & $(1)$ & (2) & (3) & $(4)$ & (5) & (6) & $(7)$ & (8) & (9) & $(10)$ & (11) & (12) \\
\hline & CAPM & FF3 & Carhart & Excess & FH7 & FH8 & Excess & FH7 & FH8 & Excess & FH7 & FH8 \\
\hline Flow $\times 13 \mathrm{~F} \times$ Post & $\begin{array}{c}0.015^{* *} \\
(2.33)\end{array}$ & $\begin{array}{c}0.017^{* *} \\
(2.36)\end{array}$ & $\begin{array}{c}0.021^{* * *} \\
(2.77)\end{array}$ & $\begin{array}{c}0.022^{* * *} \\
(3.00)\end{array}$ & $\begin{array}{c}0.018^{* *} \\
(2.32)\end{array}$ & $\begin{array}{c}0.022^{* * *} \\
(2.90)\end{array}$ & $\begin{array}{c}0.029^{* * *} \\
(2.81)\end{array}$ & $\begin{array}{c}0.018^{*} \\
(1.82)\end{array}$ & $\begin{array}{c}0.021^{* *} \\
(2.30)\end{array}$ & $\begin{array}{c}0.025^{* * *} \\
(3.18)\end{array}$ & $\begin{array}{c}0.018^{* *} \\
(2.08)\end{array}$ & $\begin{array}{c}0.022^{* *} \\
(2.56)\end{array}$ \\
\hline $13 \mathrm{~F} \times$ Post & $\begin{array}{l}-0.094 \\
(-0.36)\end{array}$ & $\begin{array}{l}0.053 \\
(0.22)\end{array}$ & $\begin{array}{l}-0.011 \\
(-0.04)\end{array}$ & $\begin{array}{l}-0.259 \\
(-1.07)\end{array}$ & $\begin{array}{l}0.169 \\
(0.60)\end{array}$ & $\begin{array}{l}0.110 \\
(0.36)\end{array}$ & $\begin{array}{c}-0.903^{* * *} \\
(-2.62)\end{array}$ & $\begin{array}{l}-0.202 \\
(-0.57)\end{array}$ & $\begin{array}{l}-0.264 \\
(-0.66)\end{array}$ & $\begin{array}{l}-0.316 \\
(-1.12)\end{array}$ & $\begin{array}{l}0.163 \\
(0.50)\end{array}$ & $\begin{array}{l}0.067 \\
(0.19)\end{array}$ \\
\hline Flow $\times 13 \mathrm{~F}$ & $\begin{array}{c}-0.013^{* *} \\
(-2.12)\end{array}$ & $\begin{array}{c}-0.013^{*} \\
(-1.79)\end{array}$ & $\begin{array}{c}-0.016^{* *} \\
(-2.25)\end{array}$ & $\begin{array}{c}-0.017^{* *} \\
(-2.39)\end{array}$ & $\begin{array}{l}-0.012 \\
(-1.52)\end{array}$ & $\begin{array}{c}-0.015^{* *} \\
(-2.08)\end{array}$ & & & & $\begin{array}{c}-0.020^{* * *} \\
(-2.60)\end{array}$ & $\begin{array}{l}-0.012 \\
(-1.47)\end{array}$ & $\begin{array}{c}-0.016^{* *} \\
(-2.07)\end{array}$ \\
\hline Flow & $\begin{array}{c}-0.011^{* * *} \\
(-3.96)\end{array}$ & $\begin{array}{c}-0.011^{* * *} \\
(-3.70)\end{array}$ & $\begin{array}{c}-0.007^{* *} \\
(-2.28)\end{array}$ & $\begin{array}{c}-0.013^{* * *} \\
(-4.29)\end{array}$ & $\begin{array}{c}-0.014^{* * *} \\
(-4.65)\end{array}$ & $\begin{array}{c}-0.013^{* * *} \\
(-4.18)\end{array}$ & $\begin{array}{c}-0.034^{* * *} \\
(-3.80)\end{array}$ & $\begin{array}{c}-0.023^{* * *} \\
(-2.92)\end{array}$ & $\begin{array}{c}-0.026^{* * *} \\
(-3.68)\end{array}$ & $\begin{array}{c}-0.013^{* * *} \\
(-4.20)\end{array}$ & $\begin{array}{c}-0.014^{* * *} \\
(-4.46)\end{array}$ & $\begin{array}{c}-0.012^{* * *} \\
(-3.92)\end{array}$ \\
\hline LogSize & $\begin{array}{c}-1.181^{* * *} \\
(-12.55)\end{array}$ & $\begin{array}{c}-1.024^{* * *} \\
(-11.43)\end{array}$ & $\begin{array}{c}-1.013^{* * *} \\
(-10.84)\end{array}$ & $\begin{array}{c}-1.531^{* * *} \\
(-15.09)\end{array}$ & $\begin{array}{c}-1.124^{* * *} \\
(-10.39)\end{array}$ & $\begin{array}{c}-1.152^{* * *} \\
(-10.18)\end{array}$ & $\begin{array}{c}-1.194^{* * *} \\
(-7.54)\end{array}$ & $\begin{array}{c}-0.955^{* * *} \\
(-6.29)\end{array}$ & $\begin{array}{c}-1.010^{* * *} \\
(-6.40)\end{array}$ & $\begin{array}{c}-1.587^{* * *} \\
(-14.21)\end{array}$ & $\begin{array}{c}-1.198^{* * *} \\
(-9.61)\end{array}$ & $\begin{array}{c}-1.216^{* * *} \\
(-9.32)\end{array}$ \\
\hline LogAge & $\begin{array}{c}-1.880^{* * *} \\
(-4.29)\end{array}$ & $\begin{array}{c}-1.980 * * * \\
(-4.56)\end{array}$ & $\begin{array}{c}-1.762^{* * *} \\
(-4.20)\end{array}$ & $\begin{array}{c}-1.563^{* * *} \\
(-3.72)\end{array}$ & $\begin{array}{c}-1.944^{* * *} \\
(-4.00)\end{array}$ & $\begin{array}{c}-1.966^{* * *} \\
(-4.11)\end{array}$ & $\begin{array}{l}-1.137 \\
(-1.21)\end{array}$ & $\begin{array}{c}-2.352^{* *} \\
(-2.42)\end{array}$ & $\begin{array}{l}-1.938^{*} \\
(-1.93)\end{array}$ & $\begin{array}{c}-1.872^{* * *} \\
(-3.74)\end{array}$ & $\begin{array}{c}-2.228^{* * *} \\
(-3.83)\end{array}$ & $\begin{array}{c}-2.229^{* * *} \\
(-3.95)\end{array}$ \\
\hline LagFlow & $\begin{array}{l}0.005^{*} \\
(1.84)\end{array}$ & $\begin{array}{c}0.005^{* *} \\
(2.05)\end{array}$ & $\begin{array}{c}0.008^{* * *} \\
(2.71)\end{array}$ & $\begin{array}{c}0.012^{* * *} \\
(3.77)\end{array}$ & $\begin{array}{l}0.002 \\
(0.49)\end{array}$ & $\begin{array}{l}0.003 \\
(0.84)\end{array}$ & $\begin{array}{l}0.007 \\
(1.07)\end{array}$ & $\begin{array}{l}-0.002 \\
(-0.39)\end{array}$ & $\begin{array}{l}-0.003 \\
(-0.47)\end{array}$ & $\begin{array}{c}0.012^{* * *} \\
(3.36)\end{array}$ & $\begin{array}{l}0.003 \\
(0.69)\end{array}$ & $\begin{array}{l}0.003 \\
(0.82)\end{array}$ \\
\hline LagRet & $\begin{array}{c}-0.110^{* * *} \\
(-7.74)\end{array}$ & $\begin{array}{c}-0.088^{* * *} \\
(-5.21)\end{array}$ & $\begin{array}{c}-0.104^{* * *} \\
(-5.54)\end{array}$ & $\begin{array}{c}-0.115^{* * *} \\
(-8.32)\end{array}$ & $\begin{array}{l}-0.024 \\
(-1.08)\end{array}$ & $\begin{array}{c}-0.068^{* * *} \\
(-3.25)\end{array}$ & $\begin{array}{l}-0.002 \\
(-0.06)\end{array}$ & $\begin{array}{l}-0.001 \\
(-0.02)\end{array}$ & $\begin{array}{l}-0.011 \\
(-0.28)\end{array}$ & $\begin{array}{c}-0.127^{* * *} \\
(-8.96)\end{array}$ & $\begin{array}{l}-0.040 \\
(-1.63)\end{array}$ & $\begin{array}{c}-0.077^{* * *} \\
(-3.42)\end{array}$ \\
\hline Volatility & $\begin{array}{c}0.060^{* * *} \\
(4.85)\end{array}$ & $\begin{array}{c}0.052^{* * *} \\
(3.64)\end{array}$ & $\begin{array}{c}0.031^{*} \\
(1.82)\end{array}$ & $\begin{array}{c}0.104^{* * *} \\
(8.01)\end{array}$ & $\begin{array}{l}0.012 \\
(0.63)\end{array}$ & $\begin{array}{l}0.011 \\
(0.63)\end{array}$ & $\begin{array}{c}0.156^{* * * *} \\
(4.63)\end{array}$ & $\begin{array}{l}0.032 \\
(0.80)\end{array}$ & $\begin{array}{l}0.023 \\
(0.52)\end{array}$ & $\begin{array}{c}0.115^{* * *} \\
(8.75)\end{array}$ & $\begin{array}{l}0.029 \\
(1.50)\end{array}$ & $\begin{array}{l}0.028 \\
(1.59)\end{array}$ \\
\hline Time FE & Yes & Yes & Yes & Yes & Yes & Yes & Yes & Yes & Yes & Yes & Yes & Yes \\
\hline Fund FE & Yes & Yes & Yes & Yes & Yes & Yes & Yes & Yes & Yes & Yes & Yes & Yes \\
\hline Observations & 52897 & 52897 & 52897 & 54725 & 54725 & 54725 & 9849 & 9849 & 9849 & 46228 & 46228 & 46228 \\
\hline Adjusted $R^{2}$ & 0.121 & 0.102 & 0.099 & 0.201 & 0.100 & 0.089 & 0.243 & 0.113 & 0.099 & 0.192 & 0.105 & 0.094 \\
\hline
\end{tabular}


Table 8: Robustness of Smart Money Effect (2)

This table repeats our baseline specification (equation 7) with additional fund-level control variables. The main specification is described in the caption of Table 3 . In Columns 1, 2, and 3, we re-estimate our baseline regression model after controlling time-invariant fund-level characteristics. The additional controls variables include the following: redemption notice period, measured in units of 30 days (RedemptionNotice), lockup period (LockUp), management fee (MgmtFee), incentive fee (IncentiveFee), the log of one plus minimum investment (MinInvestment), indicator variables for whether personal capital is committed (PersonalCapital), whether there is a high water mark provision (HWM), whether the fund uses leverage (Leveraged), and whether the fund is offshore (Offshore). Because these controls are fund-level time-invariant, we include fund style fixed-effects instead of fund fixed-effects; note that in absence of fund fixed-effects, the stand alone term $13 F$ is added back to the regression specifications. In Columns 4,5 , and 6 , we re-estimate the regression model in Columns 1, 2, and 3 after including fund company fixed-effects; note that after including fund company fixed-effects, the stand alone term $13 F$ is again redundant.

\begin{tabular}{|c|c|c|c|c|c|c|}
\hline & $\begin{array}{c}(1) \\
\text { Excess }\end{array}$ & $\begin{array}{l}(2) \\
\mathrm{FH} 7\end{array}$ & $\begin{array}{c}(3) \\
\text { FH8 }\end{array}$ & $\begin{array}{c}(4) \\
\text { Excess }\end{array}$ & $\begin{array}{l}(5) \\
\text { FH7 }\end{array}$ & $\begin{array}{l}(6) \\
\text { FH8 }\end{array}$ \\
\hline Flow $\times 13 \mathrm{~F} \times$ Post & $\begin{array}{c}0.021^{* * *} \\
(3.06)\end{array}$ & $\begin{array}{c}0.019^{* *} \\
(2.53)\end{array}$ & $\begin{array}{c}0.024^{* * *} \\
(3.08)\end{array}$ & $\begin{array}{c}0.021^{* * *} \\
(2.86)\end{array}$ & $\begin{array}{c}0.017^{* *} \\
(2.16)\end{array}$ & $\begin{array}{c}0.021^{* * *} \\
(2.78)\end{array}$ \\
\hline $13 \mathrm{~F} \times$ Post & $\begin{array}{c}-0.652^{* * *} \\
(-4.85)\end{array}$ & $\begin{array}{c}-0.431^{* * *} \\
(-2.89)\end{array}$ & $\begin{array}{c}-0.504^{* * *} \\
(-3.27)\end{array}$ & $\begin{array}{l}-0.263 \\
(-1.05)\end{array}$ & $\begin{array}{l}0.124 \\
(0.44)\end{array}$ & $\begin{array}{l}0.046 \\
(0.15)\end{array}$ \\
\hline Flow $\times 13 \mathrm{~F}$ & $\begin{array}{c}-0.015^{* *} \\
(-2.15)\end{array}$ & $\begin{array}{l}-0.011 \\
(-1.46)\end{array}$ & $\begin{array}{c}-0.014^{*} \\
(-1.91)\end{array}$ & $\begin{array}{c}-0.015^{* *} \\
(-1.99)\end{array}$ & $\begin{array}{l}-0.008 \\
(-1.05)\end{array}$ & $\begin{array}{l}-0.013^{*} \\
(-1.68)\end{array}$ \\
\hline Flow & $\begin{array}{l}-0.000 \\
(-0.16)\end{array}$ & $\begin{array}{l}-0.004 \\
(-1.39)\end{array}$ & $\begin{array}{l}-0.003 \\
(-0.92)\end{array}$ & $\begin{array}{c}-0.007^{* *} \\
(-2.29)\end{array}$ & $\begin{array}{c}-0.009^{* * *} \\
(-3.15)\end{array}$ & $\begin{array}{c}-0.008^{* *} \\
(-2.55)\end{array}$ \\
\hline $13 \mathrm{~F}$ & $\begin{array}{c}0.839^{* * *} \\
(6.72)\end{array}$ & $\begin{array}{c}0.380^{* * *} \\
(2.67)\end{array}$ & $\begin{array}{c}0.427^{* * *} \\
(2.92)\end{array}$ & & & \\
\hline LogSize & $\begin{array}{c}-0.079^{* * *} \\
(-2.89)\end{array}$ & $\begin{array}{l}-0.026 \\
(-0.76)\end{array}$ & $\begin{array}{l}-0.026 \\
(-0.73)\end{array}$ & $\begin{array}{c}-0.675^{* * *} \\
(-12.01)\end{array}$ & $\begin{array}{c}-0.489^{* * *} \\
(-8.58)\end{array}$ & $\begin{array}{c}-0.512^{* * *} \\
(-8.52)\end{array}$ \\
\hline LogAge & $\begin{array}{l}0.108 \\
(1.27)\end{array}$ & $\begin{array}{c}-0.190^{*} \\
(-1.74)\end{array}$ & $\begin{array}{l}-0.219^{*} \\
(-1.87)\end{array}$ & $\begin{array}{l}0.139 \\
(0.79)\end{array}$ & $\begin{array}{l}-0.318 \\
(-1.63)\end{array}$ & $\begin{array}{c}-0.350^{*} \\
(-1.68)\end{array}$ \\
\hline LagFlow & $\begin{array}{l}0.003 \\
(0.97)\end{array}$ & $\begin{array}{c}-0.005^{*} \\
(-1.82)\end{array}$ & $\begin{array}{l}-0.005 \\
(-1.62)\end{array}$ & $\begin{array}{l}0.004 \\
(1.12)\end{array}$ & $\begin{array}{l}-0.004 \\
(-1.19)\end{array}$ & $\begin{array}{l}-0.003 \\
(-0.81)\end{array}$ \\
\hline LagRet & $\begin{array}{c}0.060^{* * *} \\
(4.18)\end{array}$ & $\begin{array}{c}0.105^{* * *} \\
(5.02)\end{array}$ & $\begin{array}{c}0.060^{* * *} \\
(3.00)\end{array}$ & $\begin{array}{c}-0.071^{* * *} \\
(-5.24)\end{array}$ & $\begin{array}{l}0.009 \\
(0.40)\end{array}$ & $\begin{array}{c}-0.035^{*} \\
(-1.73)\end{array}$ \\
\hline Volatility & $\begin{array}{c}0.058^{* * *} \\
(5.93)\end{array}$ & $\begin{array}{l}0.006 \\
(0.50)\end{array}$ & $\begin{array}{l}0.003 \\
(0.26)\end{array}$ & $\begin{array}{c}0.092 * * * \\
(7.86)\end{array}$ & $\begin{array}{l}0.010 \\
(0.62)\end{array}$ & $\begin{array}{l}0.009 \\
(0.60)\end{array}$ \\
\hline RedemptionNotice & $\begin{array}{l}0.086 \\
(1.57)\end{array}$ & $\begin{array}{l}-0.028 \\
(-0.50)\end{array}$ & $\begin{array}{l}-0.025 \\
(-0.45)\end{array}$ & $\begin{array}{l}0.024 \\
(0.24)\end{array}$ & $\begin{array}{l}-0.119 \\
(-1.07)\end{array}$ & $\begin{array}{l}-0.100 \\
(-0.91)\end{array}$ \\
\hline LockUp & $\begin{array}{c}0.179^{* *} \\
(1.98)\end{array}$ & $\begin{array}{l}0.103 \\
(0.95)\end{array}$ & $\begin{array}{l}0.137 \\
(1.23)\end{array}$ & $\begin{array}{l}0.096 \\
(0.51)\end{array}$ & $\begin{array}{l}0.018 \\
(0.10)\end{array}$ & $\begin{array}{l}0.068 \\
(0.38)\end{array}$ \\
\hline MgmtFee & $\begin{array}{c}0.168^{*} \\
(1.88)\end{array}$ & $\begin{array}{l}-0.043 \\
(-0.35)\end{array}$ & $\begin{array}{l}-0.090 \\
(-0.64)\end{array}$ & $\begin{array}{l}0.021 \\
(0.13)\end{array}$ & $\begin{array}{l}-0.038 \\
(-0.24)\end{array}$ & $\begin{array}{l}-0.078 \\
(-0.48)\end{array}$ \\
\hline IncentiveFee & $\begin{array}{l}-0.009 \\
(-0.86)\end{array}$ & $\begin{array}{l}0.016 \\
(1.23)\end{array}$ & $\begin{array}{l}0.016 \\
(1.11)\end{array}$ & $\begin{array}{l}0.027 \\
(1.53)\end{array}$ & $\begin{array}{c}0.041^{* *} \\
(2.37)\end{array}$ & $\begin{array}{c}0.043^{* *} \\
(2.39)\end{array}$ \\
\hline MinInvestment & $\begin{array}{c}0.139 * * * \\
(4.53)\end{array}$ & $\begin{array}{c}0.142^{* * *} \\
(3.64)\end{array}$ & $\begin{array}{c}0.141^{* * *} \\
(3.40)\end{array}$ & $\begin{array}{c}0.202^{* * *} \\
(3.04)\end{array}$ & $\begin{array}{c}0.276^{* * *} \\
(2.68)\end{array}$ & $\begin{array}{c}0.301^{* * * *} \\
(2.61)\end{array}$ \\
\hline PersonalCapital & $\begin{array}{c}0.247^{* *} \\
(2.08)\end{array}$ & $\begin{array}{l}-0.058 \\
(-0.38)\end{array}$ & $\begin{array}{l}-0.117 \\
(-0.75)\end{array}$ & $\begin{array}{l}-0.565^{*} \\
(-1.68)\end{array}$ & $\begin{array}{l}-0.057 \\
(-0.14)\end{array}$ & $\begin{array}{l}-0.131 \\
(-0.30)\end{array}$ \\
\hline HWM & $\begin{array}{c}0.248^{* *} \\
(2.34)\end{array}$ & $\begin{array}{l}0.249^{*} \\
(1.95)\end{array}$ & $\begin{array}{c}0.284^{* *} \\
(2.13)\end{array}$ & $\begin{array}{l}-0.199 \\
(-1.01)\end{array}$ & $\begin{array}{l}-0.240 \\
(-1.25)\end{array}$ & $\begin{array}{l}-0.273 \\
(-1.47)\end{array}$ \\
\hline Leveraged & $\begin{array}{l}-0.020 \\
(-0.22)\end{array}$ & $\begin{array}{l}0.060 \\
(0.58)\end{array}$ & $\begin{array}{l}0.026 \\
(0.25)\end{array}$ & $\begin{array}{l}0.226 \\
(1.34)\end{array}$ & $\begin{array}{l}0.136 \\
(0.79)\end{array}$ & $\begin{array}{l}0.115 \\
(0.64)\end{array}$ \\
\hline Offshore & $\begin{array}{l}-0.098 \\
(-1.12)\end{array}$ & $\begin{array}{l}-0.055 \\
(-0.52)\end{array}$ & $\begin{array}{l}-0.051 \\
(-0.47)\end{array}$ & $\begin{array}{c}-0.409^{* * *} \\
(-2.80)\end{array}$ & $\begin{array}{c}-0.524^{* * *} \\
(-3.79)\end{array}$ & $\begin{array}{c}-0.528^{* * *} \\
(-3.88)\end{array}$ \\
\hline Time FE & Yes & Yes & Yes & Yes & Yes & Yes \\
\hline Style FE & Yes & Yes & Yes & Yes & Yes & Yes \\
\hline Company FE & No & No & No & Yes & Yes & Yes \\
\hline Observations & 52891 & 52891 & 52891 & 52798 & 52798 & 52798 \\
\hline Adjusted $R^{2}$ & 0.174 & 0.073 & 0.060 & 0.197 & 0.101 & 0.090 \\
\hline
\end{tabular}




\section{Table 9: Cross-Sectional Smart Money Analysis: Precision of Information}

This table reports the cross-sectional regression results based on the precision of information. We split the sample in the following three ways: (i) based on the number of funds reported in TASS, we split the sample to "single-fund company" and "multi-fund company"; (ii) based on whether a fund is the largest fund within a fund company; and (iii) based on whether the proportion reveled in $13 \mathrm{~F}$ is above or below the cross-sectional median. We then estimate the following regression: Performance $_{i, q+1}=\alpha_{i}+\alpha_{q}+\beta_{1}$ Flow $_{i, q} \times 13 F_{i} \times$ Post $_{i, q}+\beta_{2} 13 F_{i} \times$ Post $_{i, q}+\beta_{4}$ Flow $_{i, q} \times 13 F_{i}+$ $\beta_{5}$ Flow $_{i, q}+\gamma$ Controls $_{i, q}+\varepsilon_{i, q}$. Performance Per $_{i+1}$ is the return on fund $i$ in quarter $q+1$. All dependent variables in the regressions are FH7 factor alphas. Flow $w_{i, q}$ is the percentage fund flow of fund $i$ in quarter $q .13 F_{i}$ is an indicator for whether fund $i$ ever files Form 13F. It captures the treatment effect. Post ${ }_{i, q}$ is an indicator for whether fund $i$ has ever filed Form 13F as of quarter $q$. Controls $s_{i, q}$ is a vector of fund level controls, including the logarithm of assets under management, the logarithm of fund age in months, average fund flows in quarter $q-1, q-2$, and $q-3$, average returns in quarter $q, q-1, q-2$, and $q-3$, and the volatility of past 12 month returns. $\alpha_{i}$ and $\alpha_{q}$ are fund- and quarter-level fixed effects, respectively. We cluster standard errors at the management company level. Method (i) is reported in Columns 1 and 2, method (ii) in Columns 3 and 4, and method (iii) in Columns 5 and 6.

\begin{tabular}{|c|c|c|c|c|c|c|}
\hline & $\begin{array}{c}(1) \\
\text { Single-Fund } \\
\text { Company }\end{array}$ & $\begin{array}{c}\text { (2) } \\
\text { Multi-Fund } \\
\text { Company }\end{array}$ & $\begin{array}{c}(3) \\
\text { Largest } \\
\text { Fund }\end{array}$ & $\begin{array}{c}(4) \\
\text { Other } \\
\text { Funds }\end{array}$ & $\begin{array}{c}(5) \\
\text { Above } \\
\text { Median }\end{array}$ & $\begin{array}{c}(6) \\
\text { Below } \\
\text { Median }\end{array}$ \\
\hline Flow $\times 13 \mathrm{~F} \times$ Post & $\begin{array}{c}0.037^{* *} \\
(2.38)\end{array}$ & $\begin{array}{l}0.010 \\
(1.01)\end{array}$ & $\begin{array}{c}0.030^{* * *} \\
(2.99)\end{array}$ & $\begin{array}{l}0.007 \\
(0.55)\end{array}$ & $\begin{array}{c}0.032^{* *} \\
(2.43)\end{array}$ & $\begin{array}{l}0.011 \\
(1.03)\end{array}$ \\
\hline $13 \mathrm{~F} \times$ Post & $\begin{array}{l}-0.528 \\
(-0.95)\end{array}$ & $\begin{array}{l}0.429 \\
(1.04)\end{array}$ & $\begin{array}{l}0.017 \\
(0.05)\end{array}$ & $\begin{array}{l}0.041 \\
(0.07)\end{array}$ & $\begin{array}{l}-0.196 \\
(-0.42)\end{array}$ & $\begin{array}{l}0.412 \\
(0.89)\end{array}$ \\
\hline Flow $\times 13 \mathrm{~F}$ & $\begin{array}{c}-0.027^{*} \\
(-1.93)\end{array}$ & $\begin{array}{l}-0.006 \\
(-0.58)\end{array}$ & $\begin{array}{l}-0.015 \\
(-1.58)\end{array}$ & $\begin{array}{l}-0.007 \\
(-0.58)\end{array}$ & $\begin{array}{c}-0.024^{*} \\
(-1.96)\end{array}$ & $\begin{array}{l}-0.007 \\
(-0.61)\end{array}$ \\
\hline Flow & $\begin{array}{c}-0.019 * * * \\
(-3.78)\end{array}$ & $\begin{array}{c}-0.012^{* * *} \\
(-2.76)\end{array}$ & $\begin{array}{c}-0.018^{* * *} \\
(-5.04)\end{array}$ & $\begin{array}{l}-0.010 \\
(-1.61)\end{array}$ & $\begin{array}{c}-0.017^{* * *} \\
(-3.91)\end{array}$ & $\begin{array}{c}-0.012^{* *} \\
(-2.42)\end{array}$ \\
\hline LogSize & $\begin{array}{c}-1.445^{* * *} \\
(-8.07)\end{array}$ & $\begin{array}{c}-1.076^{* * *} \\
(-7.30)\end{array}$ & $\begin{array}{c}-1.231^{* * *} \\
(-9.61)\end{array}$ & $\begin{array}{c}-1.256^{* * *} \\
(-5.94)\end{array}$ & $\begin{array}{c}-1.319^{* * *} \\
(-8.26)\end{array}$ & $\begin{array}{c}-1.109 * * * \\
(-6.89)\end{array}$ \\
\hline LogAge & $\begin{array}{c}-2.270 * * * \\
(-2.93)\end{array}$ & $\begin{array}{c}-1.759^{* *} \\
(-2.41)\end{array}$ & $\begin{array}{c}-2.480 * * * \\
(-4.53)\end{array}$ & $\begin{array}{l}-0.363 \\
(-0.31)\end{array}$ & $\begin{array}{c}-2.447^{* * *} \\
(-3.46)\end{array}$ & $\begin{array}{l}-1.175 \\
(-1.39)\end{array}$ \\
\hline LagFlow & $\begin{array}{l}0.006 \\
(1.04)\end{array}$ & $\begin{array}{l}0.000 \\
(0.10)\end{array}$ & $\begin{array}{l}0.002 \\
(0.47)\end{array}$ & $\begin{array}{l}0.002 \\
(0.36)\end{array}$ & $\begin{array}{c}0.003 \\
(0.67)\end{array}$ & $\begin{array}{l}0.002 \\
(0.46)\end{array}$ \\
\hline LagRet & $\begin{array}{c}-0.066^{* *} \\
(-2.42)\end{array}$ & $\begin{array}{l}-0.019 \\
(-0.57)\end{array}$ & $\begin{array}{l}-0.035 \\
(-1.49)\end{array}$ & $\begin{array}{l}-0.036 \\
(-0.92)\end{array}$ & $\begin{array}{c}-0.056^{* *} \\
(-2.22)\end{array}$ & $\begin{array}{l}-0.020 \\
(-0.54)\end{array}$ \\
\hline Volatility & $\begin{array}{l}0.022 \\
(0.83)\end{array}$ & $\begin{array}{l}0.013 \\
(0.42)\end{array}$ & $\begin{array}{l}0.012 \\
(0.62)\end{array}$ & $\begin{array}{l}0.012 \\
(0.32)\end{array}$ & $\begin{array}{l}0.011 \\
(0.43)\end{array}$ & $\begin{array}{l}0.011 \\
(0.34)\end{array}$ \\
\hline Time FE & Yes & Yes & Yes & Yes & Yes & Yes \\
\hline Fund FE & Yes & Yes & Yes & Yes & Yes & Yes \\
\hline Observations & 22309 & 30554 & 37092 & 15671 & 26449 & 26338 \\
\hline Adjusted $R^{2}$ & 0.110 & 0.100 & 0.109 & 0.094 & 0.111 & 0.097 \\
\hline
\end{tabular}


Table 10: Cross-Sectional Smart Money Analysis: Flow Restrictions

This table reports the cross-sectional regression results based on whether investor can get in and out of a fund more freely. To study this, we split the sample based on the following fund characteristics: (i) whether a fund has lock-up provision; (ii) redemption frequency; (iii) redemption notice period; and (iv) subscription frequency. We then estimate the following regression: Performance ${ }_{i, q+1}=$ $\alpha_{i}+\alpha_{q}+\beta_{1}$ Flow $_{i, q} \times 13 F_{i} \times$ Post $_{i, q}+\beta_{2} 13 F_{i} \times$ Post $_{i, q}+\beta_{4}$ Flow $_{i, q} \times 13 F_{i}+\beta_{5}$ Flow $_{i, q}+\gamma$ Controls $_{i, q}+$ $\varepsilon_{i, q}$. Performance $e_{i, q+1}$ is the return on fund $i$ in quarter $q+1$. All dependent variables in the regressions are $\mathrm{FH} 7$ factor alphas. Flow $i, q$ is the percentage fund flow of fund $i$ in quarter $q .13 F_{i}$ is an indicator for whether fund $i$ ever files Form 13F. It captures the treatment effect. Post $t_{i, q}$ is an indicator for whether fund $i$ has ever filed Form 13F as of quarter $q$. Controls $s_{i, q}$ is a vector of fund level controls, including the logarithm of assets under management, the logarithm of fund age in months, average fund flows in quarter $q-1, q-2$, and $q-3$, average returns in quarter $q, q-1$, $q-2$, and $q-3$, and the volatility of past 12 month returns. $\alpha_{i}$ and $\alpha_{q}$ are fund- and quarter-level fixed effects, respectively. We cluster standard errors at the management company level. Method (i) is reported in Columns 1 and 2, method (ii) in Columns 3 and 4, method (iii) in Columns 5 and 6 , and method (iv) in Columns 7 and 8.

\begin{tabular}{|c|c|c|c|c|c|c|c|c|}
\hline & $\begin{array}{c}(1) \\
\text { Lock-Up? } \\
\text { No }\end{array}$ & $\begin{array}{c}\text { Lock-Up? } \\
\text { Yes }\end{array}$ & $\begin{array}{c}(3) \\
\text { Redemption } \\
\text { Frequency } \\
\text { Short }\end{array}$ & $\begin{array}{l}(4) \\
\text { Redemption } \\
\text { Frequency } \\
\text { Long }\end{array}$ & $\begin{array}{c}(5) \\
\text { Redemption } \\
\text { Notice } \\
\text { Short }\end{array}$ & $\begin{array}{c}(6) \\
\text { Redemption } \\
\text { Notice } \\
\text { Long }\end{array}$ & $\begin{array}{c}(7) \\
\text { Subscription } \\
\text { Frequency } \\
\text { Short }\end{array}$ & $\begin{array}{c}(8) \\
\text { Subscription } \\
\text { Frequency } \\
\text { Long }\end{array}$ \\
\hline Flow $\times 13 \mathrm{~F} \times$ Post & $\begin{array}{c}0.022^{* *} \\
(2.05)\end{array}$ & $\begin{array}{l}0.010 \\
(0.86)\end{array}$ & $\begin{array}{l}0.020^{*} \\
(1.79)\end{array}$ & $\begin{array}{l}0.012 \\
(1.05)\end{array}$ & $\begin{array}{c}0.019^{* *} \\
(2.11)\end{array}$ & $\begin{array}{l}0.017 \\
(1.03)\end{array}$ & $\begin{array}{c}0.020^{* *} \\
(2.39)\end{array}$ & $\begin{array}{l}0.007 \\
(0.22)\end{array}$ \\
\hline $13 \mathrm{~F} \times$ Post & $\begin{array}{l}0.086 \\
(0.23)\end{array}$ & $\begin{array}{l}0.534 \\
(0.98)\end{array}$ & $\begin{array}{l}0.380 \\
(0.96)\end{array}$ & $\begin{array}{l}0.318 \\
(0.75)\end{array}$ & $\begin{array}{l}0.159 \\
(0.46)\end{array}$ & $\begin{array}{l}0.229 \\
(0.46)\end{array}$ & $\begin{array}{l}0.279 \\
(0.87)\end{array}$ & $\begin{array}{l}0.125 \\
(0.12)\end{array}$ \\
\hline Flow $\times 13 \mathrm{~F}$ & $\begin{array}{l}-0.014 \\
(-1.33)\end{array}$ & $\begin{array}{l}-0.007 \\
(-0.63)\end{array}$ & $\begin{array}{l}-0.008 \\
(-0.75)\end{array}$ & $\begin{array}{l}-0.017 \\
(-1.55)\end{array}$ & $\begin{array}{l}-0.009 \\
(-1.08)\end{array}$ & $\begin{array}{c}-0.032^{* *} \\
(-2.19)\end{array}$ & $\begin{array}{l}-0.011 \\
(-1.34)\end{array}$ & $\begin{array}{l}-0.018 \\
(-0.50)\end{array}$ \\
\hline Flow & $\begin{array}{c}-0.013^{* * *} \\
(-3.69)\end{array}$ & $\begin{array}{c}-0.017^{* *} \\
(-2.43)\end{array}$ & $\begin{array}{c}-0.013^{* * *} \\
(-3.57)\end{array}$ & $\begin{array}{c}-0.011^{*} \\
(-1.81)\end{array}$ & $\begin{array}{c}-0.017^{* * *} \\
(-5.15)\end{array}$ & $\begin{array}{l}0.008 \\
(0.96)\end{array}$ & $\begin{array}{c}-0.014^{* * *} \\
(-4.49)\end{array}$ & $\begin{array}{l}-0.014 \\
(-1.11)\end{array}$ \\
\hline LogSize & $\begin{array}{c}-1.127^{* * *} \\
(-8.51)\end{array}$ & $\begin{array}{c}-1.170^{* * *} \\
(-6.02)\end{array}$ & $\begin{array}{c}-0.988^{* * *} \\
(-7.15)\end{array}$ & $\begin{array}{c}-1.355^{* * *} \\
(-7.50)\end{array}$ & $\begin{array}{c}-1.212^{* * *} \\
(-9.88)\end{array}$ & $\begin{array}{c}-0.587^{* * *} \\
(-2.70)\end{array}$ & $\begin{array}{c}-1.040^{* * *} \\
(-9.80)\end{array}$ & $\begin{array}{c}-2.127^{* * *} \\
(-4.67)\end{array}$ \\
\hline LogAge & $\begin{array}{c}-1.958^{* * *} \\
(-3.03)\end{array}$ & $\begin{array}{c}-2.040^{* * *} \\
(-2.84)\end{array}$ & $\begin{array}{c}-2.691^{* * *} \\
(-3.43)\end{array}$ & $\begin{array}{l}-1.065 \\
(-1.49)\end{array}$ & $\begin{array}{c}-1.934^{* * *} \\
(-3.39)\end{array}$ & $\begin{array}{c}-3.321^{* * *} \\
(-3.47)\end{array}$ & $\begin{array}{c}-2.265^{* * *} \\
(-4.09)\end{array}$ & $\begin{array}{l}0.506 \\
(0.26)\end{array}$ \\
\hline LagFlow & $\begin{array}{l}0.002 \\
(0.57)\end{array}$ & $\begin{array}{l}0.001 \\
(0.10)\end{array}$ & $\begin{array}{l}0.002 \\
(0.53)\end{array}$ & $\begin{array}{l}0.001 \\
(0.21)\end{array}$ & $\begin{array}{l}0.004 \\
(0.95)\end{array}$ & $\begin{array}{l}-0.012 \\
(-1.50)\end{array}$ & $\begin{array}{l}0.002 \\
(0.60)\end{array}$ & $\begin{array}{l}-0.000 \\
(-0.03)\end{array}$ \\
\hline LagRet & $\begin{array}{l}-0.034 \\
(-1.38)\end{array}$ & $\begin{array}{l}-0.009 \\
(-0.22)\end{array}$ & $\begin{array}{c}-0.091^{* * *} \\
(-2.81)\end{array}$ & $\begin{array}{l}0.036 \\
(1.27)\end{array}$ & $\begin{array}{l}-0.036 \\
(-1.45)\end{array}$ & $\begin{array}{c}0.102^{* *} \\
(2.18)\end{array}$ & $\begin{array}{l}-0.030 \\
(-1.19)\end{array}$ & $\begin{array}{l}0.015 \\
(0.28)\end{array}$ \\
\hline Volatility & $\begin{array}{l}0.025 \\
(1.11) \\
\end{array}$ & $\begin{array}{l}-0.023 \\
(-0.75) \\
\end{array}$ & $\begin{array}{l}0.039 \\
(1.58)\end{array}$ & $\begin{array}{l}-0.018 \\
(-0.68) \\
\end{array}$ & $\begin{array}{l}0.012 \\
(0.58)\end{array}$ & $\begin{array}{l}-0.004 \\
(-0.14) \\
\end{array}$ & $\begin{array}{l}0.016 \\
(0.82) \\
\end{array}$ & $\begin{array}{l}-0.017 \\
(-0.38) \\
\end{array}$ \\
\hline Time FE & Yes & Yes & Yes & Yes & Yes & Yes & Yes & Yes \\
\hline Fund FE & Yes & Yes & Yes & Yes & Yes & Yes & Yes & Yes \\
\hline Observations & 36537 & 16360 & 27888 & 25009 & 46912 & 5985 & 46328 & 6569 \\
\hline Adjusted $R^{2}$ & 0.104 & 0.103 & 0.127 & 0.087 & 0.104 & 0.100 & 0.107 & 0.079 \\
\hline
\end{tabular}


Table 11: Cross-Sectional Smart Money Analysis: Information Acquisition

This table reports the cross-sectional regression results based on the amount of investor attention paid to the fund. We split funds based on the median level of investor attention. Our measures of investor attention are based on: downloads of any 13F filings (Panel A); downloads of any filings (Panel B); unique IPs accessing any 13F filing (Panel C); and unique IPs accessing any filing (Panel D). We then estimate the following regression: Performance $i_{i, q+1}=\alpha_{i}+\alpha_{q}+\beta_{1}$ Flow $_{i, q} \times 13 F_{i} \times$ Post $_{i, q}+\beta_{2} 13 F_{i} \times$ Post $_{i, q}+\beta_{4}$ Flow $_{i, q} \times 13 F_{i}+\beta_{5}$ Flow $_{i, q}+\gamma$ Controls $_{i, q}+\varepsilon_{i, q}$. Performance $i, q+1$ is the return on fund $i$ in quarter $q+1$. All dependent variables in the regressions are $\mathrm{FH} 7$ factor alphas. Flow $w_{i, q}$ is the percentage fund flow of fund $i$ in quarter $q .13 F_{i}$ is an indicator for whether fund $i$ ever files Form 13F. It captures the treatment effect. Post $t_{i, q}$ is an indicator for whether fund $i$ has ever filed Form 13F as of quarter $q$. Controls $s_{i, q}$ is a vector of fund level controls, including the logarithm of assets under management, the logarithm of fund age in months, average fund flows in quarter $q-1, q-2$, and $q-3$, average returns in quarter $q, q-1, q-2$, and $q-3$, and the volatility of past 12 month returns. $\alpha_{i}$ and $\alpha_{q}$ are fund- and quarter-level fixed effects, respectively. We cluster standard errors at the management company level.

\begin{tabular}{|c|c|c|c|c|c|c|c|c|}
\hline & $\begin{array}{l}\text { Panel } \\
\text { Downloa } \\
\text { portion } \\
\text { Traffic }\end{array}$ & $\begin{array}{l}: \# \text { of } \\
\text { s as pro- } \\
f \text { all } 13 \mathrm{~F}\end{array}$ & $\begin{array}{l}\text { Panel } \\
\text { Downloa } \\
\text { proporti } \\
\text { EDGAR }\end{array}$ & $\begin{array}{lll}: & \# \quad \text { of } \\
\text { ls } & & \text { as } \\
n & \text { of all } & \text { all } \\
\text { Traffic } & \end{array}$ & $\begin{array}{l}\text { Panel } \\
\text { unique I } \\
\text { portion } \\
\text { Traffic }\end{array}$ & $\begin{array}{l}\quad \# \text { of } \\
\text { s as pro- } \\
f \text { all } 13 F\end{array}$ & $\begin{array}{l}\text { Panel } \\
\text { Unique } \\
\text { proporti } \\
\text { EDGAR }\end{array}$ & $\begin{array}{l}: \# \text { of } \\
\text { IPs as } \\
n \text { of all } \\
\text { Traffic }\end{array}$ \\
\hline & (1) & $(2)$ & (3) & (4) & $(5)$ & (6) & (7) & (8) \\
\hline & High & Low & High & Low & High & Low & High & Low \\
\hline Flow $\times 13 \mathrm{~F} \times$ Post & $\begin{array}{c}0.021^{*} \\
(1.88)\end{array}$ & $\begin{array}{l}0.010 \\
(0.79)\end{array}$ & $\begin{array}{l}0.021^{*} \\
(1.88)\end{array}$ & $\begin{array}{l}0.009 \\
(0.67)\end{array}$ & $\begin{array}{l}0.020^{*} \\
(1.82)\end{array}$ & $\begin{array}{l}0.014 \\
(1.19)\end{array}$ & $\begin{array}{l}0.020^{*} \\
(1.87)\end{array}$ & $\begin{array}{l}0.013 \\
(1.09)\end{array}$ \\
\hline $13 \mathrm{~F} \times$ Post & $\begin{array}{l}-0.124 \\
(-0.28)\end{array}$ & $\begin{array}{l}-0.386 \\
(-0.93)\end{array}$ & $\begin{array}{l}-0.142 \\
(-0.32)\end{array}$ & $\begin{array}{l}-0.397 \\
(-0.93)\end{array}$ & $\begin{array}{l}-0.014 \\
(-0.03)\end{array}$ & $\begin{array}{l}-0.536 \\
(-1.26)\end{array}$ & $\begin{array}{l}-0.050 \\
(-0.11)\end{array}$ & $\begin{array}{l}-0.489 \\
(-1.12)\end{array}$ \\
\hline Flow & $\begin{array}{c}-0.023^{* *} \\
(-2.38)\end{array}$ & $\begin{array}{c}-0.026^{* *} \\
(-2.37)\end{array}$ & $\begin{array}{c}-0.023^{* *} \\
(-2.47)\end{array}$ & $\begin{array}{c}-0.024^{* *} \\
(-2.22)\end{array}$ & $\begin{array}{c}-0.026^{* *} \\
(-2.56)\end{array}$ & $\begin{array}{c}-0.024^{* *} \\
(-2.23)\end{array}$ & $\begin{array}{c}-0.026^{* * *} \\
(-2.66)\end{array}$ & $\begin{array}{c}-0.023^{* *} \\
(-2.13)\end{array}$ \\
\hline LogSize & $\begin{array}{c}-0.825 * * * \\
(-6.05)\end{array}$ & $\begin{array}{c}-1.060^{* * *} \\
(-5.69)\end{array}$ & $\begin{array}{c}-0.832^{* * *} \\
(-6.07)\end{array}$ & $\begin{array}{c}-1.034^{* * *} \\
(-5.59)\end{array}$ & $\begin{array}{c}-0.841^{* * * *} \\
(-6.30)\end{array}$ & $\begin{array}{c}-1.040^{\text {*** }} \\
(-5.43)\end{array}$ & $\begin{array}{c}-0.837^{* * * *} \\
(-6.22)\end{array}$ & $\begin{array}{c}-1.027^{* * *} \\
(-5.32)\end{array}$ \\
\hline LogAge & $\begin{array}{c}-2.560^{* * *} \\
(-3.00)\end{array}$ & $\begin{array}{c}-2.327^{* *} \\
(-2.46)\end{array}$ & $\begin{array}{c}-2.621^{* * *} \\
(-3.10)\end{array}$ & $\begin{array}{c}-2.338^{* *} \\
(-2.46)\end{array}$ & $\begin{array}{c}-2.688^{* * *} \\
(-3.18)\end{array}$ & $\begin{array}{c}-1.960^{* *} \\
(-2.09)\end{array}$ & $\begin{array}{c}-2.232^{* * *} \\
(-2.65)\end{array}$ & $\begin{array}{c}-2.603^{* * *} \\
(-2.91)\end{array}$ \\
\hline LagFlow & $\begin{array}{l}-0.012 \\
(-1.63)\end{array}$ & $\begin{array}{l}0.006 \\
(0.77)\end{array}$ & $\begin{array}{l}-0.011 \\
(-1.51)\end{array}$ & $\begin{array}{l}0.005 \\
(0.63)\end{array}$ & $\begin{array}{l}-0.010 \\
(-1.34)\end{array}$ & $\begin{array}{l}0.003 \\
(0.46)\end{array}$ & $\begin{array}{l}-0.010 \\
(-1.35)\end{array}$ & $\begin{array}{l}0.004 \\
(0.50)\end{array}$ \\
\hline LagRet & $\begin{array}{l}-0.007 \\
(-0.19)\end{array}$ & $\begin{array}{l}-0.053 \\
(-1.39)\end{array}$ & $\begin{array}{l}-0.002 \\
(-0.06)\end{array}$ & $\begin{array}{l}-0.059 \\
(-1.54)\end{array}$ & $\begin{array}{l}-0.017 \\
(-0.46)\end{array}$ & $\begin{array}{l}-0.038 \\
(-1.05)\end{array}$ & $\begin{array}{l}-0.018 \\
(-0.48)\end{array}$ & $\begin{array}{l}-0.044 \\
(-1.15)\end{array}$ \\
\hline Volatility & $\begin{array}{l}0.006 \\
(0.15)\end{array}$ & $\begin{array}{l}0.047 \\
(0.87)\end{array}$ & $\begin{array}{l}0.005 \\
(0.12)\end{array}$ & $\begin{array}{l}0.050 \\
(0.92)\end{array}$ & $\begin{array}{l}0.007 \\
(0.19)\end{array}$ & $\begin{array}{l}0.050 \\
(0.90)\end{array}$ & $\begin{array}{l}0.006 \\
(0.17)\end{array}$ & $\begin{array}{l}0.057 \\
(0.98)\end{array}$ \\
\hline Time FE & Yes & Yes & Yes & Yes & Yes & Yes & Yes & Yes \\
\hline Fund FE & Yes & Yes & Yes & Yes & Yes & Yes & Yes & Yes \\
\hline Observations & 10260 & 7544 & 10307 & 7497 & 10330 & 7474 & 10560 & 7244 \\
\hline Adjusted $R^{2}$ & 0.101 & 0.129 & 0.103 & 0.129 & 0.098 & 0.135 & 0.097 & 0.141 \\
\hline
\end{tabular}

${ }^{*} p<0.1,{ }^{* *} p<0.05,{ }^{* * *} p<0.01$ 
Table 12: Summary Statistics: FoFs Holdings

This table presents the summary statistics of our sample of 127 fund-of-hedge funds ("FoFs") between 2004Q3 and 2016Q4. Following Gao et al. (2019), we identify and collect quarterly holdings of FoFs form SEC filings. We match each underlying hedge fund with TASS and Form ADV, and classify them to $13 \mathrm{~F}$-filing funds or non-filing funds. Panel A shows the summary statistics of sample FoFs at the end of 2004; Panel B shows the summary statistics of sample FoFs at the end of 2010; Panel C shows the summary statistics of sample FoFs at the end of 2016. FoF AUM is the summation of current values of all underlying hedge funds; \# of Holdings is the number of hedge funds currently held; \# of Filer Held is the number of underlying hedge funds categorized as "filer"; Filer AUM is the proportion of FoF's assets that invested in "filer" hedge funds; \# of Non-Filer Held is the number of underlying hedge funds categorized as "non-filer"; Non-Filer AUM is the proportion of FoF's assets that invested in "non-filer" hedge funds.

\begin{tabular}{lccccc}
\hline \hline \multicolumn{7}{c}{ Mean } & StdDev & Q1 & Median & Q3 \\
\hline Panel A: 2004Q4 (Number of FoFs: 49) & & \\
\hline FoF AUM (millions \$) & 188.751 & 335.787 & 50.827 & 75.795 & 188.969 \\
\# of Holdings & 23.714 & 13.342 & 15.000 & 21.000 & 29.000 \\
\# of Filer Held & 6.592 & 4.354 & 4.000 & 6.000 & 8.000 \\
Filer AUM (\%) & 29.879 & 12.936 & 18.361 & 31.361 & 37.814 \\
\# of Non-Filer Held & 6.184 & 4.091 & 3.000 & 6.000 & 7.000 \\
Non-Filer AUM (\%) & 27.140 & 12.912 & 20.528 & 25.481 & 29.516 \\
\hline Panel B: 2010Q4 (Number of FoFs: 46) & & \\
\hline FoF AUM (millions \$) & 392.293 & 881.760 & 30.470 & 118.927 & 430.999 \\
\# of Holdings & 30.522 & 28.226 & 17.000 & 23.500 & 37.000 \\
\# of Filer Held & 16.630 & 10.586 & 10.000 & 14.000 & 22.000 \\
Filer AUM (\%) & 65.055 & 19.046 & 51.545 & 66.124 & 78.300 \\
\# of Non-Filer Held & 8.870 & 14.938 & 2.000 & 6.500 & 11.000 \\
Non-Filer AUM (\%) & 23.405 & 12.739 & 12.763 & 24.570 & 33.938 \\
\hline Panel C: 2016Q4 (Number of FoFs: 45) & & \\
\hline FoF AUM (millions \$) & 411.710 & 817.576 & 55.833 & 140.936 & 462.664 \\
\# of Holdings & 28.333 & 26.061 & 16.000 & 24.000 & 31.000 \\
\# of Filer Held & 18.467 & 10.235 & 12.000 & 17.000 & 23.000 \\
Filer AUM (\%) & 74.555 & 18.281 & 66.034 & 77.632 & 88.837 \\
\# of Non-Filer Held & 7.644 & 15.094 & 1.000 & 4.000 & 10.000 \\
Non-Filer AUM (\%) & 19.797 & 16.737 & 7.581 & 15.838 & 28.460 \\
\hline \hline
\end{tabular}


Table 13: FoFs Holdings-Based Analysis: Full Sample

This table reports the holdings-based analysis using our sample of FoFs and the entire sample of underlying hedge funds. At the end of each calendar quarter, we assign underlying hedge funds in each FoF's portfolio to one of two portfolios. We then compute the quarterly returns on the two portfolios over the next quarter. Within a given FoF-quarter, hedge funds are valueweighted and then we average calendar time portfolios across FoFs and quarters. Standard errors are clustered using various methods (no clustering, clustered by quarter, clustered by FoF, and double-clustered by FoF and quarter) and are reported in parentheses. The first two columns report the average returns of the two portfolios, and the third column reports return of the longshort portfolio constructed using these two portfolios. In Panel A, we examine FoF's 13F-filing holdings and its non-filing holdings. In Panel B, we examine 13F-filing hedge funds currently held and 13-filing hedge funds currently not held.

\begin{tabular}{lccc}
\hline \hline Panel A: Filer Portfolio vs NonFiler Portfolio & \\
\hline & NonFiler & Filer & Filer-NonFiler \\
\cline { 2 - 4 } Raw Returns (\% per quarter) & 1.353 & 1.585 & 0.232 \\
t-statistics: & & & \\
No Clustering & $(12.17)^{* * *}$ & $(17.57)^{* * *}$ & $(2.60)^{* * *}$ \\
Clustered by Quarter & $(2.89)^{* * *}$ & $(3.37)^{* * *}$ & $(1.79)^{*}$ \\
Clustered by FoF & $(13.09)^{* * *}$ & $(21.20)^{* * *}$ & $(2.29)^{* *}$ \\
Clustered by FoF and Quarter & $(2.90)^{* * *}$ & $(3.39)^{* * *}$ & $(1.68)^{*}$ \\
\hline Panel B: Filer Held vs Filer Not Held & & \\
\hline & Filer Not Held & Filer Held & Held-NotHeld \\
\cline { 2 - 4 } & 1.246 & 1.459 & 0.213 \\
Raw Returns (\% per quarter) & \multicolumn{3}{|c}{} \\
t-statistics: & $(18.40)^{* * *}$ & $(16.66)^{* * *}$ & $(3.63)^{* * *}$ \\
No Clustering & $(2.58)^{* * *}$ & $(3.03)^{* * *}$ & $(2.26)^{* *}$ \\
Clustered by Quarter & $(29.58)^{* * *}$ & $(20.89)^{* * *}$ & $(3.17)^{* * *}$ \\
Clustered by FoF & $(2.60)^{* * *}$ & $(3.05)^{* * *}$ & $(2.13)^{* *}$ \\
\hline Clustered by FoF and Quarter & &
\end{tabular}

${ }^{*} p<0.1,{ }^{* *} p<0.05,{ }^{* * *} p<0.01$ 
Table 14: FoFs Holdings-Based Analysis: Non-Local Funds

This table reports the holdings-based analysis using our sample of FoFs and the subset of non-local hedge funds. An underlying hedge fund is defined as non-local if it is located in a Metropolitan Statistical Area (MSA) that is different from that of the FoF. At the end of each calendar quarter, we assign underlying hedge funds in each FoF's portfolio to one of two portfolios. We then compute the quarterly returns on the two portfolios over the next quarter. Within a given FoF-quarter, hedge funds are value-weighted and then we average calendar time portfolios across FoFs and quarters. Standard errors are clustered using various methods (no clustering, clustered by quarter, clustered by FoF, and double-clustered by FoF and quarter) and are reported in parentheses. The first two columns report the average returns of the two portfolios, and the third column reports return of the long-short portfolio constructed using these two portfolios. In Panel A, we examine FoF's 13F-filing holdings and its non-filing holdings. In Panel B, we examine 13F-filing hedge funds currently held and 13-filing hedge funds currently not held.

\begin{tabular}{|c|c|c|c|}
\hline \multicolumn{4}{|c|}{ Panel A: Filer Portfolio vs NonFiler Portfolio } \\
\hline & NonFiler & Filer & Filer-NonFiler \\
\hline Raw Returns (\% per quarter) & 1.170 & 1.521 & 0.351 \\
\hline \multicolumn{4}{|l|}{ t-statistics: } \\
\hline No Clustering & $(8.89)^{* * *}$ & $(14.96)^{* * *}$ & $(2.98)^{* * *}$ \\
\hline Clustered by Quarter & $(2.42)^{* *}$ & $(3.14)^{* * *}$ & $(2.35)^{* *}$ \\
\hline Clustered by FoF & $(8.95)^{* * *}$ & $(17.84)^{* * *}$ & $(2.69)^{* * *}$ \\
\hline Clustered by FoF and Quarter & $(2.42)^{* *}$ & $(3.16)^{* * *}$ & $(2.20)^{* *}$ \\
\hline \multicolumn{4}{|c|}{ Panel B: Filer Held vs Filer Not Held } \\
\hline & Filer Not Held & Filer Held & Held-NotHeld \\
\hline Raw Returns (\% per quarter) & 1.202 & 1.450 & 0.248 \\
\hline \multicolumn{4}{|l|}{ t-statistics: } \\
\hline No Clustering & $(16.87)^{* * *}$ & $(15.02)^{* * *}$ & $(3.57)^{* * *}$ \\
\hline Clustered by Quarter & $(2.40)^{* *}$ & $(2.96)^{* * *}$ & $(3.06)^{* * *}$ \\
\hline Clustered by FoF & $(28.48)^{* * *}$ & $(18.64)^{* * *}$ & $(3.13)^{* * *}$ \\
\hline Clustered by FoF and Quarter & $(2.41)^{* *}$ & $(2.98)^{* * *}$ & $(2.77)^{* * *}$ \\
\hline
\end{tabular}

${ }^{*} p<0.1,{ }^{* *} p<0.05,{ }^{* * *} p<0.01$ 